Prepared in cooperation with the U.S. Bureau of Reclamation and the Colorado River Basin Salinity Control Forum

\title{
Assessment of Dissolved-Solids Loading to the Colorado River in the Paradox Basin Between the Dolores River and Gypsum Canyon, Utah
}

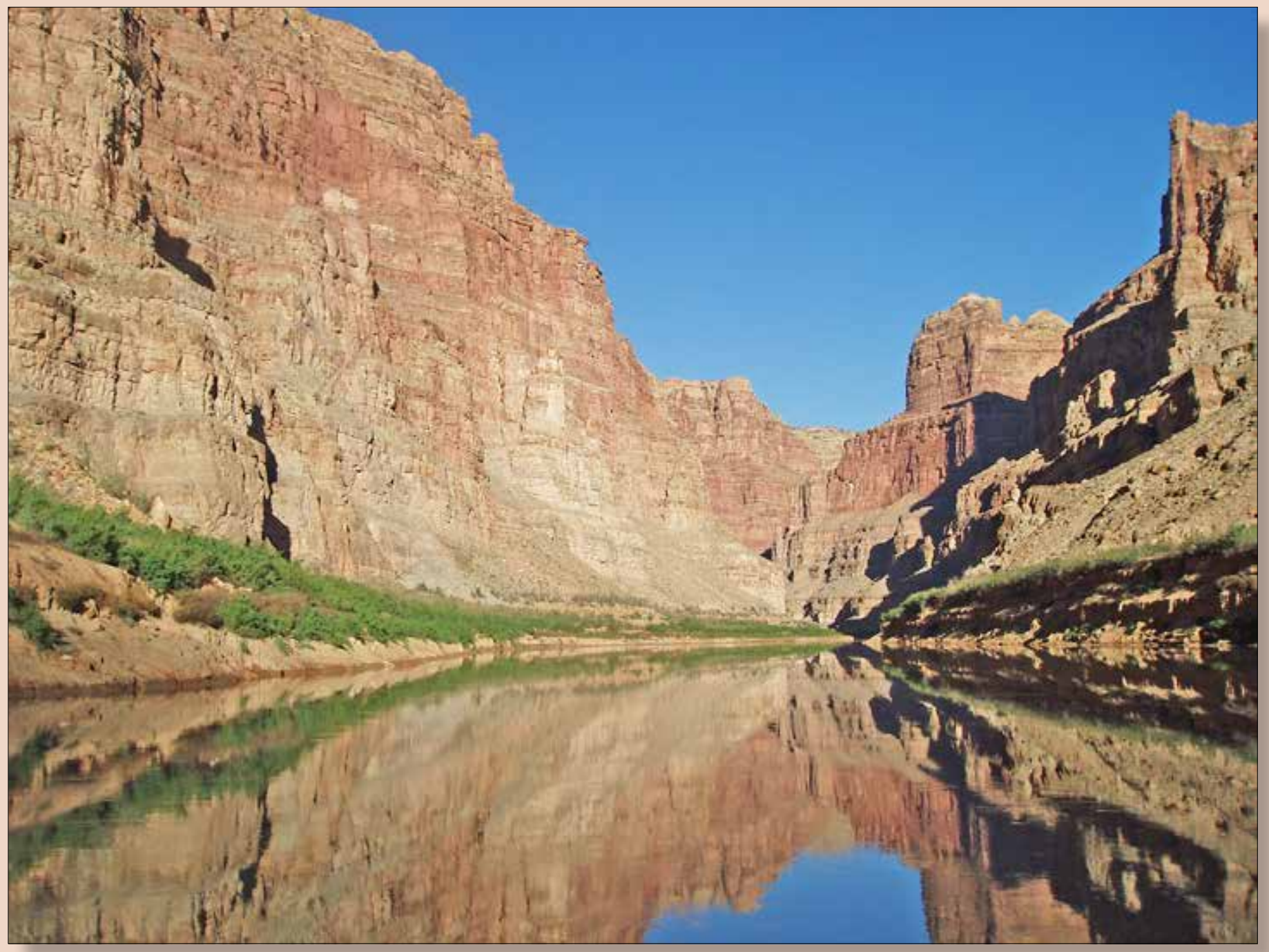

Scientific Investigations Report 2014-5031 



\section{Assessment of Dissolved-Solids Loading to the Colorado River in the Paradox Basin Between the Dolores River and Gypsum Canyon, Utah}

By Christopher L. Shope and Steven J. Gerner

Prepared in cooperation with the U.S. Bureau of Reclamation and the Colorado

River Basin Salinity Control Forum

Scientific Investigations Report 2014-5031 


\title{
U.S. Department of the Interior SALLY JEWELL, Secretary
}

\section{U.S. Geological Survey \\ Suzette M. Kimball, Acting Director}

\author{
U.S. Geological Survey, Reston, Virginia: 2014
}

For more information on the USGS - the Federal source for science about the Earth, its natural and living resources, natural hazards, and the environment, visit http://www.usgs.gov or call 1-888-ASK-USGS.

For an overview of USGS information products, including maps, imagery, and publications, visit http://Www.usgs.gov/pubprod.

To order this and other USGS information products, visit http://store.usgs.gov.

Any use of trade, firm, or product names is for descriptive purposes only and does not imply endorsement by the U.S. Government.

Although this information product, for the most part, is in the public domain, it also may contain copyrighted materials as noted in the text. Permission to reproduce copyrighted items must be secured from the copyright owner.

Suggested citation:

Shope, C.L., and Gerner, S.J., 2014, Assessment of dissolved-solids loading to the Colorado River in the Paradox Basin between the Dolores River and Gypsum Canyon, Utah: U.S. Geological Survey Scientific Investigations Report 2014-5031, 18 p.

ISSN 2328-0328 


\section{Contents}

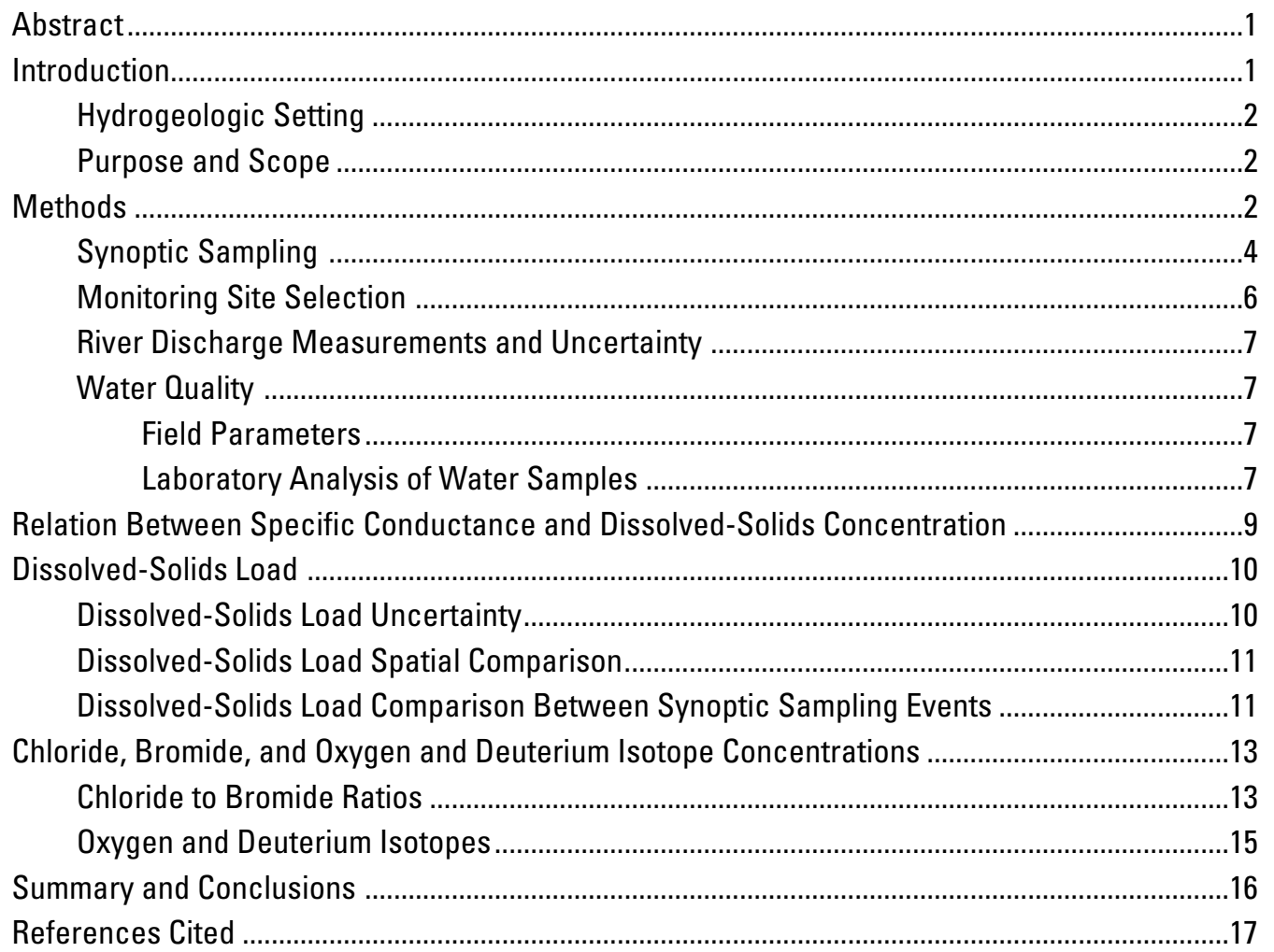

\section{Figures}

1. Map showing location of the study area in the Upper Colorado River Basin, southeastern Utah

2. Graphs showing discharge and specific conductance at U.S. Geological Survey streamgaging station Colorado River near Cisco, UT for the 2010 and 2011 synoptic sampling periods

3. Photograph showing typical configuration of the acoustic Doppler current profiler mounted on a tri-hull boat tethered to an inflatable boat

4. Graphs showing specific conductance and total dissolved solids least-squares relation developed from samples collected along the Colorado River between the Dolores River and Gypsum Canyon during four synoptic periods. $A$, Data from both Colorado River and tributary monitoring sites for dissolved-solids concentration; $B$, Data from Colorado River monitoring sites with error bars representing the accuracy in specific conductance from the calibration results and the accuracy in dissolved-solids concentration from the method reporting limit; and C, Data from the Colorado River monitoring sites plus historical specificconductance and dissolved-solids concentration data collected at U.S. Geological Survey streamgaging station Colorado River near Cisco, Utah 
5. Graphs showing dissolved-solids loading for each of the four synoptic sampling periods along the Colorado River between the Dolores River and Gypsum Canyon, southeastern Utah

6. Graphs showing chloride $A$, and bromide $B$, concentrations in the Colorado River and major tributaries during four synoptic sampling periods along the Colorado River between the Dolores River and Gypsum Canyon; and $C$, Chloride:bromide ratios for samples collected from the Colorado River and tributary monitoring sites ...14

7. Graph showing oxygen and deuterium concentrations in samples collected from the Colorado River and tributary monitoring sites between the Dolores River and Gypsum Canyon, southeastern Utah

\section{Tables}

1. Water-quality monitoring locations along the Colorado River between the Dolores River and Gypsum Canyon, southeastern Utah

2. Average daily discharge, specific conductance, and calculated dissolved-solids concentration for synoptic periods 2, 3, and 4 at U.S. Geological Survey streamgaging station Colorado River near Cisco, Utah

3. Summary of physical properties, laboratory analyzed water-quality parameters, and analytical methods used in assessing dissolved-solids loading to the Colorado River between the Dolores River and Gypsum Canyon, southeastern Utah 


\section{Conversion Factors, Datums, and Water-Quality Units}

Inch/Pound to SI

\begin{tabular}{lcl}
\hline \multicolumn{1}{c}{ Multiply } & By & \multicolumn{1}{c}{ To obtain } \\
\hline foot $(\mathrm{ft})$ & Length & \\
mile $(\mathrm{mi})$ & 0.3048 & meter $(\mathrm{m})$ \\
& 1.609 & kilometer $(\mathrm{km})$ \\
\hline acre & Area & \\
square mile $\left(\mathrm{mi}^{2}\right)$ & 0.004047 & square kilometer $\left(\mathrm{km}^{2}\right)$ \\
& 2.590 & square kilometer $\left(\mathrm{km}^{2}\right)$ \\
\hline cubic foot per second $\left(\mathrm{ft}^{3} / \mathrm{s}\right)$ & Flow rate & \\
\hline & 28.3165 & liter per second $(\mathrm{L} / \mathrm{s})$ \\
\hline ton & Mass & \\
ton per day (ton/d) & 0.9072 & metric ton $(\mathrm{mton})$ \\
& 0.9072 & metric ton per day $(\mathrm{mton} / \mathrm{d})$ \\
\hline
\end{tabular}

Temperature in degrees Celsius $\left({ }^{\circ} \mathrm{C}\right)$ may be converted to degrees Fahrenheit $\left({ }^{\circ} \mathrm{F}\right)$ as follows:

${ }^{\circ} \mathrm{F}=\left(1.8 x^{\circ} \mathrm{C}\right)+32$

Temperature in degrees Fahrenheit $\left({ }^{\circ} \mathrm{F}\right)$ may be converted to degrees Celsius $\left({ }^{\circ} \mathrm{C}\right)$ as follows:

${ }^{\circ} \mathrm{C}=\left({ }^{\circ} \mathrm{F}-32\right) / 1.8$

Vertical coordinate information is referenced to the North American Vertical Datum of 1988 (NAVD 88).

Horizontal coordinate information is referenced to the North American Datum of 1983 (NAD 83).

Altitude, as used in this report, refers to distance above the vertical datum.

Specific conductance is given in microsiemens per centimeter at 25 degrees Celsius $(\mu \mathrm{S} / \mathrm{cm}$ at $\left.25^{\circ} \mathrm{C}\right)$.

Concentrations of chemical constituents in water are given either in milligrams per liter (mg/L) or micrograms per liter $(\mu \mathrm{g} / \mathrm{L})$. 


\title{
Assessment of Dissolved-Solids Loading to the Colorado River in the Paradox Basin Between the Dolores River and Gypsum Canyon, Utah
}

\author{
By Christopher L. Shope and Steven J. Gerner
}

\section{Abstract}

Salinity loads throughout the Colorado River Basin have been a concern over recent decades due to adverse impacts on population, natural resources, and regional economics. With substantial financial resources and various reclamation projects, the salt loading to Lake Powell and associated dissolvedsolids concentrations in the Lower Colorado River Basin have been substantially reduced. The Colorado River between its confluence with the Dolores River and Lake Powell traverses a physiographic area where saline sedimentary formations and evaporite deposits are prevalent. However, the dissolved-solids loading in this area is poorly understood due to the paucity of water-quality data. From 2003 to 2011, the U.S. Geological Survey in cooperation with the U.S. Bureau of Reclamation conducted four synoptic sampling events to quantify the salinity loading throughout the study reach and evaluate the occurrence and impacts of both natural and anthropogenic sources. The results from this study indicate that under latesummer base-flow conditions, dissolved-solids loading in the reach is negligible with the exception of the Green River, and that variations in calculated loads between synoptic sampling events are within measurement and analytical uncertainties. The Green River contributed approximately 22 percent of the Colorado River dissolved-solids load, based on samples collected at the lower end of the study reach. These conclusions are supported by water-quality analyses for chloride and bromide, and the results of analyses for the stable isotopes of oxygen and deuterium. Overall, no significant sources of dissolved-solids loading from tributaries or directly by groundwater discharge, with the exception of the Green River, were identified in the study area.

\section{Introduction}

Annual economic damages related to salinity in the Colorado River Basin exceed \$383 million, impact more than 36 million people, and adversely affect over 4.5 million irrigated acres of land (Gardner and Young, 1985; U.S. Bureau of
Reclamation, 2005). On average, the Upper Colorado River Basin (UCRB) annually discharges about 6 million tons of dissolved solids (Kenney and others, 2009; U.S. Bureau of Reclamation, 2011). Fifty-five percent of the dissolved solids are associated with natural surface runoff and groundwater flow paths, 37 percent is attributed to irrigated agricultural lands, and the remaining 8 percent is from evaporative processes and municipal and industrial sources (Iorns and others, 1965; U.S. Environmental Protection Agency, 1971; U.S. Bureau of Reclamation, 2005). A protracted multi-year drought since 1999 has occurred throughout the UCRB with the exception of water years 2005, 2008, and 2011. During this time, salinity concentration has increased and salinity loading has decreased, although the numeric salinity criteria on the Colorado River below Hoover Dam have not been exceeded (U.S. Bureau of Reclamation, 2011). The U.S. Environmental Protection Agency (1971) attributes 47 percent of the natural source loading in the UCRB above Hoover Dam to geologic formations high in dissolvable materials, consistent with formations throughout the Paradox structural basin. Dissolved solids from these geologic sources enter streams through surface runoff, point source spring discharge, and diffuse groundwater discharge (Kenney and others, 2009; U.S. Bureau of Reclamation, 2011).

In 1974, Congress enacted the Colorado River Basin Salinity Control Act to enhance and protect the water quality of the Colorado River. In 1995, the U.S. Bureau of Reclamation (Reclamation) was tasked to implement a basin-wide salinity control program. Salt loading to Lake Powell and dissolvedsolids concentration contributions to the Lower Colorado River Basin have been substantially reduced due to significant financial investment and a variety of reclamation projects (Barnett, 2008). Implementation of salinity control measures on private agricultural lands through the Reclamation Basin States Program and the U.S. Department of Agriculture (USDOA) Environmental Quality Incentives Program also have resulted in substantial reductions. Prior to mitigation efforts by Reclamation (U.S. Bureau of Reclamation, 2005), as much as 205,000 tons of dissolved solids were annually discharged to the Dolores River via the alluvium in Paradox Valley (Chafin, 2003; U.S. Bureau of Reclamation, 2005). 
In 1996, Reclamation commenced operation of the Paradox Valley Unit, a series of brine-withdrawal wells completed in alluvium along the Dolores River and a deep-injection well to dispose of the brine, to decrease the amount of salt transported to the river. Within 4 years, wells in the Paradox Valley Unit annually intercepted more than 90 percent of the dissolved solids that previously discharged to the river. The average daily dissolved-solids load for the period from 1998 through 2001 decreased from approximately 313 to 29 tons/d (Chafin, 2003). However, this decrease may have been partially due to decreased precipitation during the latter part of the study period, which decreased brine flux from the Paradox Valley from May 2000 through September 2001 (Chafin, 2003). There are numerous salt valleys and salt anticlines adjacent to the Colorado River and its tributaries from the confluence with the Dolores River downstream to Lake Powell (fig. 1). The Colorado Salinity Control Forum is concerned that these salt valleys and anticlines could contribute to the salinity load in the Colorado River Basin.

\section{Hydrogeologic Setting}

The Paradox Basin underlies approximately $12,000 \mathrm{mi}^{2}$ of the UCRB in southeastern Utah and southwestern Colorado (fig. 1). The Paradox Basin is defined as the area of the Colorado Plateau that is underlain by a sequence of Pennsylvanianage evaporites, composed mostly of halite (salt) beds (Hite and Lohman, 1973; Rush and others, 1982). The stratigraphic units underlying the regional plateau generally dip gently to the northwest (Rush and others, 1982). The partially confined evaporites are underlain by a lower Paleozoic aquifer that includes Mississippian-age dolomites and is generally considered porous and permeable (Hanshaw and Hill, 1969; Hood and Danielson, 1979; Rush and others, 1982). The evaporite deposits are overlain by the more permeable Mesozoic sandstone aquifer, consisting of a thick sequence of 11 northwesterly-dipping stratigraphic units (Rush and others, 1982). Although much of the Mesozoic sandstone aquifer is unsaturated, with the exception of minor influential perched segments, the individual stratigraphic units vary substantially in permeability (Rush and others, 1982).

The maximum thickness of the evaporite beds ranges from 7,000 to $14,000 \mathrm{ft}$ (Hite, 1961; Rush and others, 1982) and overburden ranges from 1,600 to more than $3,000 \mathrm{ft}$ (Hite, 1961; Gutierrez, 2004). Throughout much of the region, evaporites have undergone minimal dissolution, likely due to self-sealing of the salt units. Cater (1970) states that as little as $492 \mathrm{ft}$ of overburden are required to initiate plastic deformation of halite. Because the salt beds can deform, flow, and self-seal (Hite and Lohman, 1973), the deformed layers transmit minimal groundwater, which limits dissolution to the upper surface of the evaporite beds. Therefore, salt dissolution likely occurs only along the upper surface (Hite and Lohman, 1973; Rush and others, 1980; Wollitz and others, 1982). Salt anticlines where overlying Mesozoic sandstones were not deposited, are locations of extensive salt dissolution (Hite and Lohman, 1973; Rush and others, 1982). The formation of salt anticlines and salt dissolution structures is induced by pressure changes at depth, which cause the buoyant salt to flow upward. The sedimentary strata above the salt layer deform into an anticline and groundwater seeps through deformation cracks and dissolves the salt. Ductile downwarping or brittle collapse occurs when the overlying strata subside and a graben valley bounded by a series of normal faults is formed (e.g. Moab Valley, Paradox Valley). Along the hinge zone of the collapsed structure, the strata roll into the graben and large joints form to accommodate the movement. Subsequently, the graben valley begins to fill with sediment (Gutierrez, 2004; Trudgill, 2011). Gutierrez (2004) describes the processes of the crustal collapse geometry above Paradox Basin salt anticlines in more detail. Local faults and fractures may contribute to lateral and vertical connectivity, control flow direction and rates, or compartmentalize groundwater systems between the stratigraphic units. Brines have been observed discharging from the upper member of the Hermosa Formation immediately overlying the evaporite beds near localized faults along the axis of the Cane Creek Anticline (Huntoon, 1977).

\section{Purpose and Scope}

The primary goal of the Colorado River Basin Salinity Control Program and participating federal agencies is the cost-effective reduction of salinity into the Colorado River. This report presents estimates of total dissolved-solids loads in the Colorado River and selected tributaries, in the river reach between its confluence with the Dolores River and Gypsum Canyon above Lake Powell. These estimates were derived from multiple sets of synoptic streamflow measurements and water samples that were collected by the U.S. Geological Survey (USGS) in cooperation with Reclamation and analyzed for dissolved-solids concentrations. The synoptic measurements and sampling were done in 2003, twice in 2010, and in 2011, during September or October of each of the specified years. Results were used to assess locations of potential dissolvedsolids loading and sources. The methods used to compute these estimates, along with the limitations of the results are presented.

\section{Methods}

The dissolved-solids load estimates derived for the study reach along the Colorado River are the product of the dissolved-solids concentration and river discharge. Synoptic measurements of instantaneous river discharge and water chemistry samples were collected at least once, and as many as 4 times at each of 20 monitoring sites along the Colorado River and major tributaries in the study reach to quantify the salinity load (fig. 1). Discharge estimates were completed with a combination of acoustic Doppler current profiler (ADCP) 


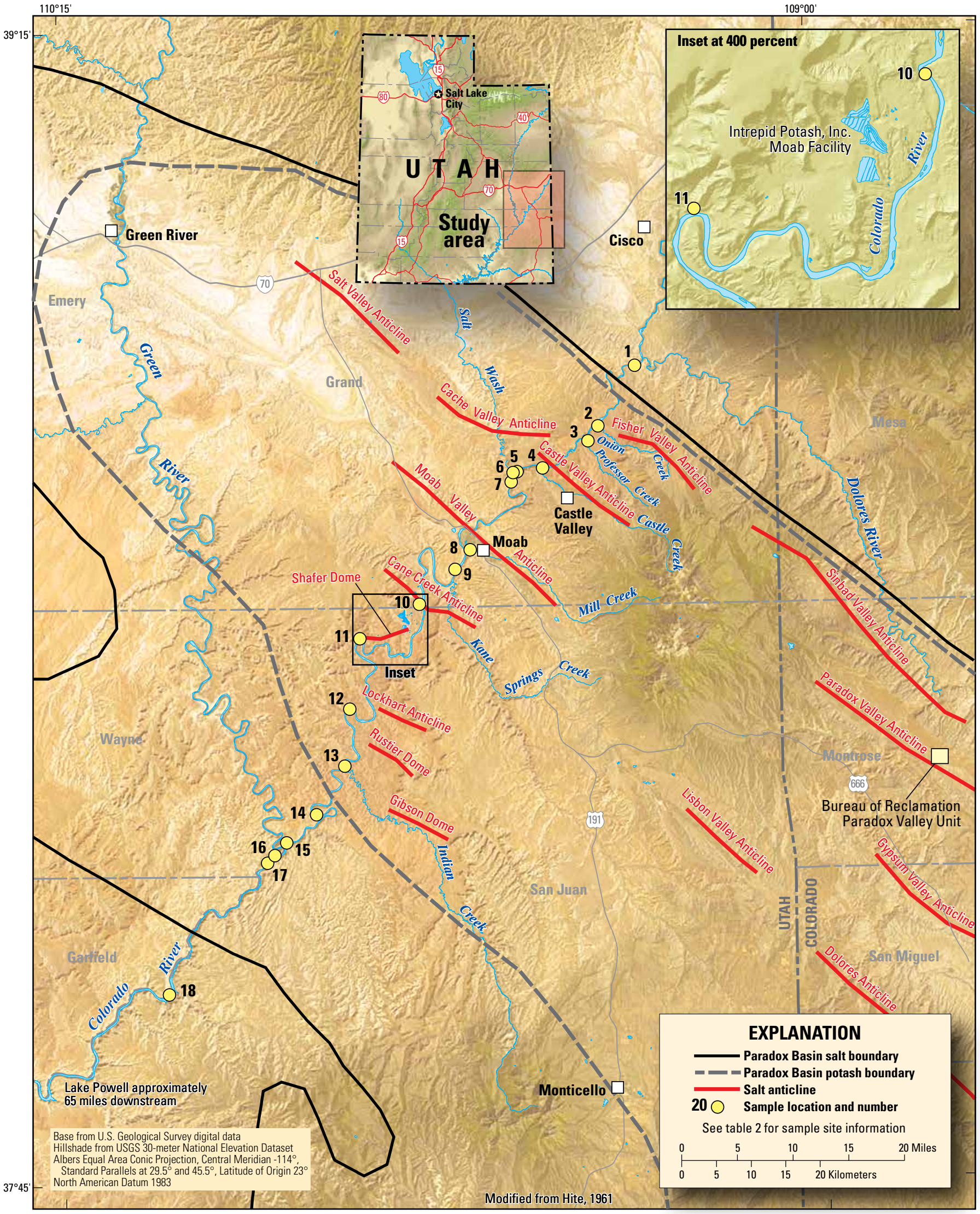

Figure 1. Location of the study area in the Upper Colorado River Basin (UCRB), southeastern Utah. 
measurements, a USGS gaging station, and FlowTracker acoustic Doppler velocimeter (ADV) measurements (fig. 2). Depth- and width-integrated composite samples were collected for water-quality analysis. Specific measurement techniques are described in detail in subsequent sections of this report. Monitoring sites were selected along the Colorado River bracketing salt valleys and immediately upstream and downstream of major tributaries.

\section{Synoptic Sampling}

The relation between environmental impacts and the associated stream chemistry is often investigated through synoptic or "snapshot" sampling, where surface water is collected from a number of sites along a reach or across a watershed in a short period of time (Fetter, 1994; Clow and others, 1996; Grayson and others, 1997; Eyre and Pepperell, 1999). If the stream

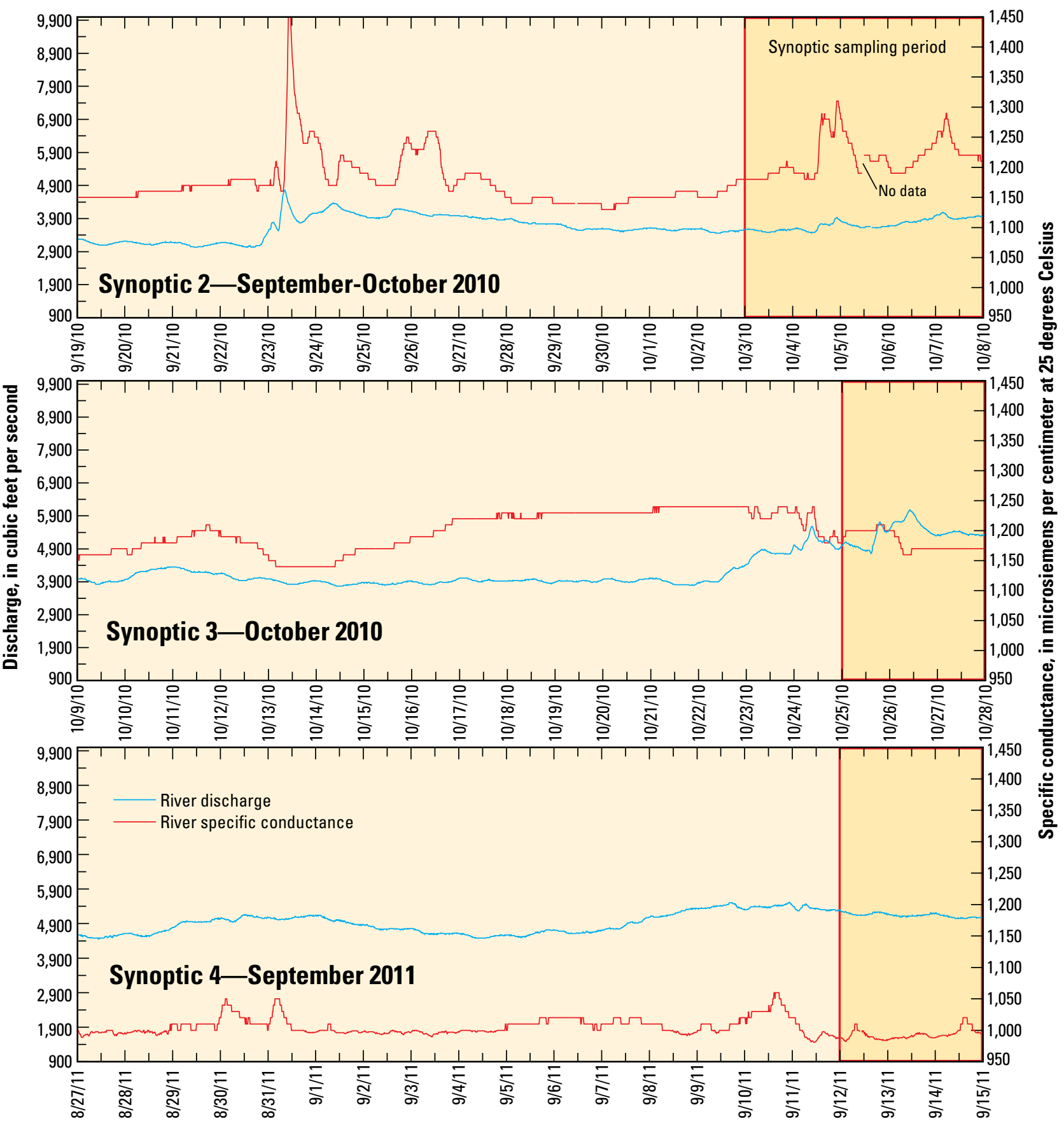

Figure 2. Discharge and specific conductance at U.S. Geological Survey streamgaging station Colorado River near Cisco, UT (09180500) for the 2010 and 2011 synoptic sampling periods. 
discharge is relatively constant throughout the sampling period, synoptic sampling can be used to study spatial stream chemistry variability (Grayson and others, 1997). Synoptic studies, referred to as synoptics in this report, are typically conducted during base-flow (low flow) conditions when groundwater contributions dominate streamflow. Synoptics also were planned during base-flow conditions when meteorological conditions were stable for the previous 5 to 10 days and were expected to remain stable throughout the investigation period.

The synoptic measurements of streamflow and water chemistry sampling were completed over four periods in three different years between 2003 and 2011. The initial synoptic was conducted from September 16, 2003, to September 17, 2003, and included the reach from Colorado River at J L Eddy (table 1, site 383015109392301) to Colorado River near Spanish Bottom (table 1, site 380942109553000) as part of a previous USGS investigation. The second synoptic was conducted from October 3, 2010, to October 7, 2010, and focused on the upper reach of the study area from the USGS streamflowgaging station Colorado River near Cisco, UT (table 1, site 09180500) to the monitoring site Colorado River at J L Eddy, approximately $14.6 \mathrm{mi}$ downstream of Moab Valley (fig. 1). The entire length of the study reach from the Colorado River near Cisco, UT streamgage to the monitoring site Colorado River at Gypsum Canyon (site 375958110043601 ) (fig. 1), was sampled during the third synoptic from October 25, 2010, to October 27, 2010. However, the only measurement completed in the upper part of the Colorado River reach above the Colorado River at J L Eddy monitoring site was at the Colorado River near Cisco, UT streamgage. The fourth synoptic was conducted from September 12, 2011, through September 14, 2011, and included the upper reach between the Colorado River near Cisco, UT streamgage and the Colorado River at King's Bottom monitoring site (site 383256109354801), located upstream of Kane Springs Creek. Monitoring sites are summarized in table 1 . The time series data for river discharge and specific conductance measured at the Colorado River near Cisco, UT streamgage (09180500) are presented for the 2010 and 2011 synoptics and the previous 15 days (fig. 2). The average daily discharge, specific conductance, and dissolvedsolids concentration at the Colorado River near Cisco, UT streamgage for each synoptic are presented in table 2.

The second synoptic coincided with two separate precipitation events that occurred on October 4 and October 6, 2010. To assess the effect of this precipitation event on river discharge and water quality, data from USGS streamgage Colorado River near Cisco, UT (09180500) were analyzed. Average daily discharge during the second synoptic varied from a minimum of 3,540 to a maximum of $3,950 \mathrm{ft}^{3} / \mathrm{s}$ (table 2), a change in discharge of about 11 percent. The average daily discharge over the previous 6 days was relatively stable. The range in specific conductance over the second synoptic was from 1,170 to $1,240 \mu \mathrm{S} / \mathrm{cm}$. Interestingly, the specific conductance was positively correlated with the discharge; as river discharge increased, specific conductance increased. Conceptually, the positively correlated increase in specific conductance indicates that surface salts were flushed into the Colorado River by this precipitation event. Although the majority of the increase in discharge may have been associated with tributary inputs of higher salinity, the relative dissolved-solids load is negligible, as discussed later in this report.

Table 1. Water-quality monitoring locations along the Colorado River between the Dolores River and Gypsum Canyon, southeastern Utah.

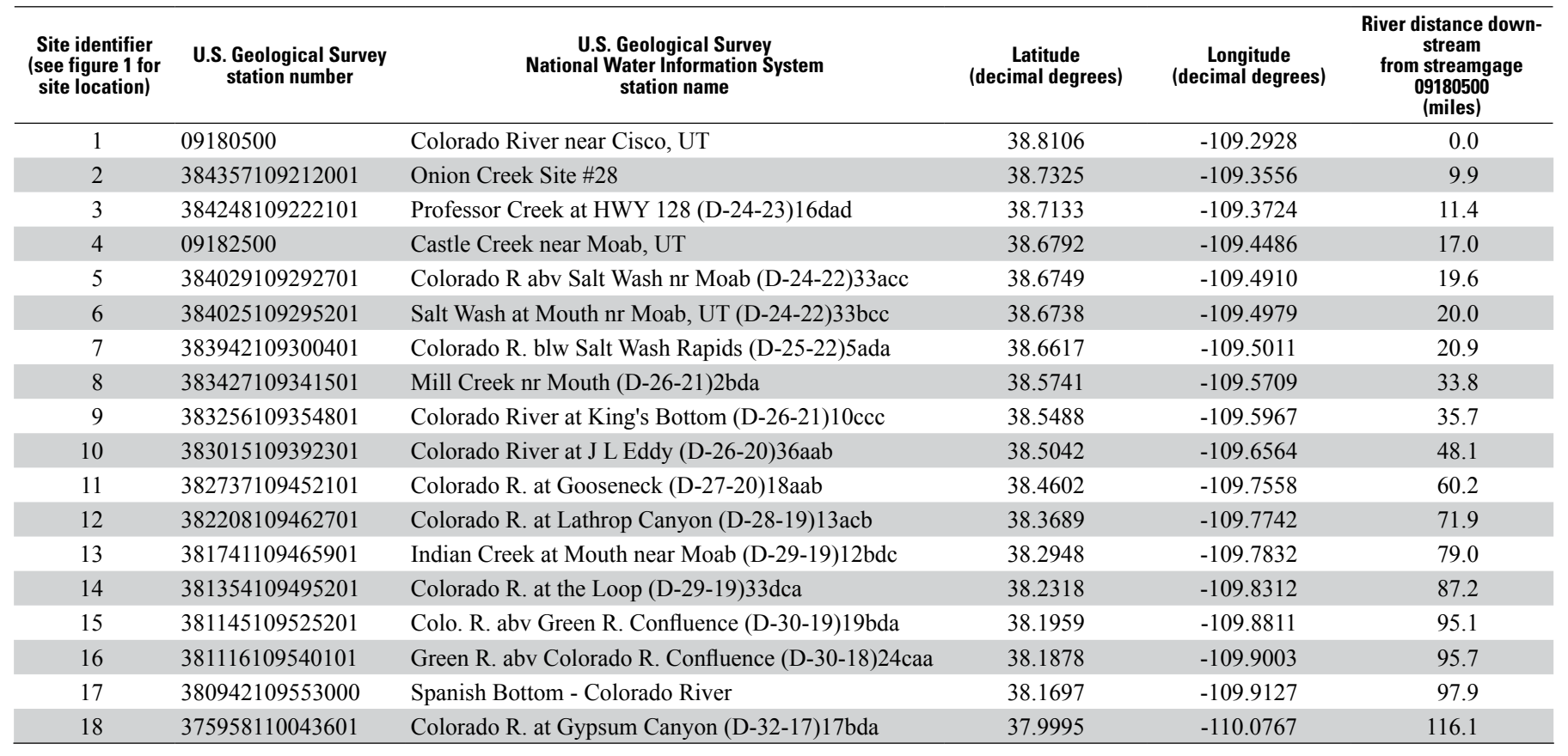




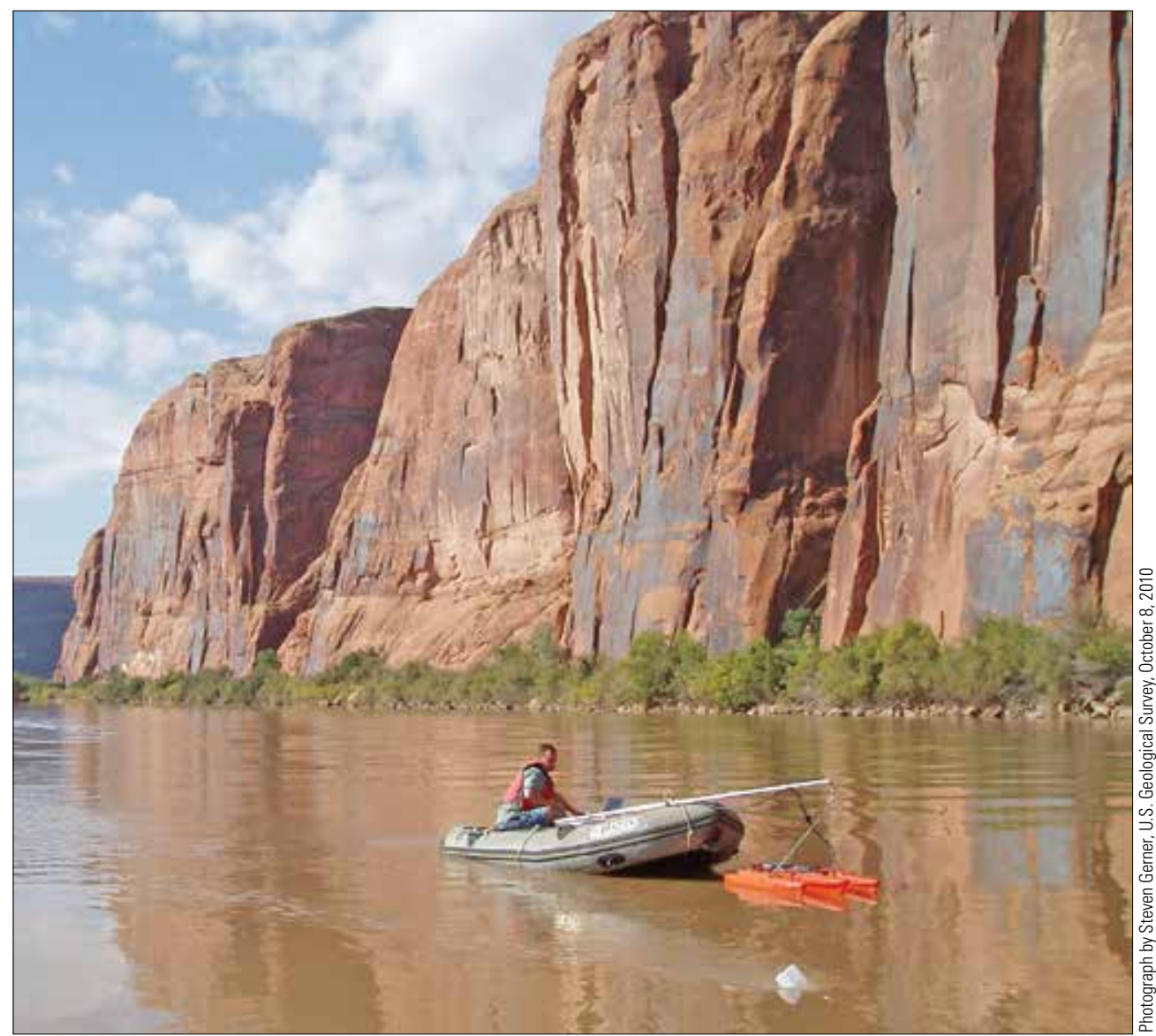

Figure 3. Typical configuration of the acoustic Doppler current profiler (ADCP) mounted on a tri-hull boat tethered to an inflatable boat. Photograph taken on the Colorado River at King's Bottom near Moab, Utah, with south facing aspect.

The third synoptic, beginning on October 25, 2010, was immediately preceded by a precipitation event that increased discharge of the Colorado River at the Cisco, UT streamgage by 22 percent. Discharge then remained relatively steady during the synoptic. The average daily discharge during the third synoptic varied from a minimum of 5,020 to a maximum of $5,670 \mathrm{ft}^{3} / \mathrm{s}$, and the average daily specific conductance varied from 1,170 to $1,200 \mu \mathrm{S} / \mathrm{cm}$ (table 2). Throughout the third synoptic and the preceding 3 days, the specific conductance was negatively correlated with river discharge. This indicates that as discharge increases, the specific conductance decreases and is consistent with the model of instream salinity dilution.

The fourth synoptic occurred during a period of relatively stable river discharge with an average daily discharge varying between 5,090 and 5,240 $\mathrm{ft}^{3} / \mathrm{s}$. This synoptic was preceded by a nearly 7-day period of minor fluctuations, likely due to upstream water management and storage changes. Although variability in the average daily specific conductance ranged between 990 and $999 \mu \mathrm{S} / \mathrm{cm}$, the magnitude was less than and over a smaller range than the previous two synoptics (table 2).

On the basis of data collected from the USGS streamgage Colorado River near Cisco, UT (09180500), the amount of variability in river discharge, specific conductance, and the dissolved-solids concentration was estimated. Discharge varied less than 12,13 , and 3 percent for synoptics 2,3 , and 4 , respectively. The specific conductance varied substantially less, at less than 6,3 , and 1 percent for each of the synoptics. The variability in dissolved-solids concentration for each of the synoptics was less than 7, 3, and 1 percent. These results are well within the total uncertainty and therefore indicate that the impacts of precipitation changes during individual synoptics are not influential on overall dissolved-solids concentration. Therefore, the discharge, specific conductance, and dissolved-solids loading data were not adjusted or normalized to accommodate event-based changes throughout each of the synoptics.

\section{Monitoring Site Selection}

River discharge and dissolved-solids concentration were determined for selected locations on the Colorado River and its tributaries in the study reach. Monitoring sites were selected based on accessibility, influence of tributaries, quality of discharge measurement cross sections and field parameters, and the proximity to potential dissolved-solids point loading sources. A list of monitoring sites is provided in table 1. 
Table 2. Average daily discharge, specific conductance, and calculated dissolved-solids concentration for synoptic periods 2, 3 , and 4 at U.S. Geological Survey streamgaging station Colorado River near Cisco, Utah.

[Abbreviations: $\mathrm{ft}^{3} / \mathrm{s}$, cubic feet per second; $\mu \mathrm{S} / \mathrm{cm}$, microsiemens per centimeter; ${ }^{\circ} \mathrm{C}$, degrees Celsius; mg/L, milligrams per liter]

\begin{tabular}{|c|c|c|c|}
\hline \multicolumn{4}{|c|}{$\begin{array}{l}\text { U.S. Geological Survey streamgage } \\
\text { Colorado River near Cisco, UT (09180500) }\end{array}$} \\
\hline $\begin{array}{l}\text { Measurement } \\
\text { date }\end{array}$ & $\underset{\left(f \mathbf{t}^{3} / \mathbf{s}\right)}{\text { Discharge }}$ & $\begin{array}{c}\text { Specific } \\
\text { conductance } \\
\left(\mu \mathrm{S} / \mathrm{cm} \text { at } 25^{\circ} \mathrm{C}\right)\end{array}$ & $\begin{array}{c}\text { Dissolved- } \\
\text { solids concentration } \\
\text { (mg/L) }\end{array}$ \\
\hline \multicolumn{4}{|c|}{ Synoptic 2} \\
\hline $10 / 3 / 10$ & 3,540 & 1,190 & 758 \\
\hline $10 / 4 / 10$ & 3,650 & 1,230 & 785 \\
\hline $10 / 5 / 10$ & 3,680 & 1,220 & 782 \\
\hline $10 / 6 / 10$ & 3,800 & 1,210 & 772 \\
\hline $10 / 7 / 10$ & 3,950 & 1,240 & 791 \\
\hline $10 / 8 / 10$ & 3,930 & 1,170 & 743 \\
\hline minimum & 3,540 & 1,170 & 743 \\
\hline maximum & 3,950 & 1,240 & 791 \\
\hline mean & 3,760 & 1,210 & 772 \\
\hline \multicolumn{4}{|c|}{ Synoptic 3} \\
\hline $10 / 25 / 10$ & 5,120 & 1,200 & 766 \\
\hline $10 / 26 / 10$ & 5,670 & 1,170 & 748 \\
\hline $10 / 27 / 10$ & 5,360 & 1,170 & 745 \\
\hline $10 / 28 / 10$ & 5,020 & 1,170 & 745 \\
\hline minimum & 5,020 & 1,170 & 745 \\
\hline maximum & 5,670 & 1,200 & 766 \\
\hline mean & 5,290 & 1,180 & 751 \\
\hline \multicolumn{4}{|c|}{ Synoptic 4} \\
\hline $9 / 12 / 11$ & 5,190 & 991 & 621 \\
\hline $9 / 13 / 11$ & 5,140 & 990 & 621 \\
\hline $9 / 14 / 11$ & 5,090 & 999 & 627 \\
\hline $9 / 15 / 11$ & 5,240 & 990 & 621 \\
\hline minimum & 5,090 & 990 & 621 \\
\hline maximum & 5,240 & 999 & 627 \\
\hline mean & 5,170 & 992 & 622 \\
\hline
\end{tabular}

\section{River Discharge Measurements and Uncertainty}

Measurements were completed using an 18-ft rigid-hull inflatable boat for the first synoptic, a 12 -ft inflatable boat for the second and fourth synoptics, and a National Park Service catamaran raft for the third synoptic. Discharge was measured with an ADCP coupled with a differential global positioning system (DGPS). The ADCP was mounted on a small tri-hull boat, which was tethered to the larger inflatable boat (fig. 3).

Discharge measurements were made using standard USGS methods outlined in Mueller and Wagner (2009). Stage, discharge, specific conductance, and water temperature from USGS gaging station Colorado River near Cisco, UT
(09180500), and at three temporary gage locations, Colorado River above Green River confluence (site 381145109525201), Colorado River at Lathrop Canyon (site 382208109462701), and Colorado River at J L Eddy (site 383015109392301) were monitored during the synoptics. An In-Situ, Inc. AquaTroll 200 barometrically compensated level logger was used at each temporary gage location to continuously monitor river stage height, specific conductance, and water temperature. Discharge of smaller tributaries was made with a FlowTracker ADV using the velocity-area technique (Buchanan and Somers, 1969; Rantz and others, 1982a, b).

Discharge at sites on the Colorado and Green Rivers was measured by an ADCP with multiple transects at each site to determine a single average discharge for the site. The accuracy of the measurement is dependent on many factors not measured with the ADCP. These factors include measuring section characteristics, vertical distribution, change in stage, wind, and instrument condition (Turnipseed and Sauer, 2010). Under optimal conditions, measurement error using these methods is typically less than plus or minus 5 percent. All discharge measurements were qualitatively classified as "Good" according to standard USGS protocol (Turnipseed and Sauer, 2010). Therefore, measurement accuracy is greater than 95 percent.

\section{Water Quality}

\section{Field Parameters}

Depth- and width-integrated water-quality samples from the Colorado and Green Rivers were collected by boat from a river cross section using a DH-95 isokinetic sampler. Field parameters were measured with a YSI 600QS multi-parameter water-quality sonde, calibrated according to standard USGS protocols, and attached to a 15-pound weight. The sonde was deployed to the midpoint of the total water depth at five flow-weighted locations perpendicular to the riverbank, based on the Equal Discharge Increment (EDI) technique (Edward and Glysson, 1999). Specific conductance, dissolved-oxygen concentration, water temperature, and $\mathrm{pH}$ were calculated as the median of all the samples at each monitoring site transect. Alkalinity was measured in the field by titration using water from the integrated sample. Field parameters were measured and water-quality samples were collected using standard protocols documented in the USGS National Field Manual for the Collection of Water-Quality Data (U.S. Geological Survey, variously dated).

\section{Laboratory Analysis of Water Samples}

Water samples were filtered in the field using a disposable 0.45 -micron capsule filter and a peristaltic pump. During the September 2003 synoptic, samples were analyzed for major anions and cations in order to derive total dissolved-solids (TDS) concentration by sum of constituents (SOC) and residue 
on evaporation (ROE). For the second and third synoptics in October 2010, additional water-quality analyses were completed that included hardness, calcium, magnesium, potassium, sodium, chloride, fluoride, bromide, silica, sulfate, iron, manganese, and oxygen and deuterium isotopes. Although alkalinity titrations were done in the field, they were also verified in the laboratory on selected samples. Samples collected during the fourth synoptic were analyzed for the same constituents as in the second and third synoptics, with the exception of iron and the stable isotopes of oxygen and deuterium. Chemical constituents, analytical methods, and minimum reporting levels are shown in table 3 .

Field-based quality assurance/quality control (QA/QC) samples were not collected for water-quality samples. However, the USGS Branch of Quality Systems monitors and assesses the quality of environmental data and documents the variability and bias from laboratory samples. Laboratory regression equations derived from the Inorganic Blind Sample Project were used to set criteria for the Third Party Check QC samples. The continuing calibration verification solution criteria used for QA/QC samples are typically plus or minus 10 percent. Therefore, the uncertainty in bromide, chloride, and dissolved-solids concentration analyses is presented as plus or minus 10 percent.

Residue on evaporation (ROE) is determined by weighing the dried residue remaining after evaporation of the volatile portion of an aliquot of the water sample; ROE was analyzed for most samples. Additionally, selected samples were analyzed for major ions, and the dissolved-solids concentrations of these samples were calculated by the SOC. For these calculations, laboratory alkalinity values reported as milligrams per liter $\mathrm{CaCO}_{3}$, were converted to bicarbonate $\left(\mathrm{HCO}_{3}^{-}\right)$ concentration by dividing the alkalinity value by 0.8202 (Hem, 1989). Field-based measurements of total alkalinity were also determined by calculating the bicarbonate concentration from the titration.

Dissolved-solids concentrations from both SOC and ROE were compared to evaluate consistency between the methods. The ratio of the dissolved-solids concentration from SOC to the dissolved-solids concentration from ROE varied from

Table 3. Summary of physical properties, laboratory analyzed water-quality parameters, and analytical methods used in assessing dissolved-solids loading to the Colorado River between the Dolores River and Gypsum Canyon, southeastern Utah.

[Abbreviations: $\mathrm{ft} 3 / \mathrm{s}$, cubic feet per second; ADCP, acoustic Doppler current profiler; $\mu \mathrm{S} / \mathrm{cm}$, microsiemens per centimeter; ${ }^{\circ} \mathrm{C}$, degrees Celsius; mg/L, milligrams per liter; $\%$, percent; $\mu \mathrm{g} / \mathrm{L}$, micrograms per liter; permil, parts per thousand; IC, ion-exchange chromatography; ICP, inductively coupled plasma spectrometry; IRMS, isotope-ratio mass spectrometry; NA, not applicable]

\begin{tabular}{|c|c|c|c|c|}
\hline Measurement or constituent & Unit & Field method & Analytical method & Minimum reporting level \\
\hline \multicolumn{5}{|c|}{ Physical properties } \\
\hline Discharge, instantaneous & $\mathrm{ft}^{3} / \mathrm{s}$ & Mid-Interval, ADCP & & Variable \\
\hline Specific conductance & $\mu \mathrm{S} / \mathrm{cm}$ at $25^{\circ} \mathrm{C}$ & Point, Multiparameter sonde & & 1 \\
\hline $\mathrm{pH}$ & standard units & Point, Multiparameter sonde & & 0.1 \\
\hline Water temperature & ${ }^{\circ} \mathrm{C}$ & Point, Multiparameter sonde & & 0.1 \\
\hline Dissolved oxygen & $\mathrm{mg} / \mathrm{L}, \%$ saturation & Point, Multiparameter sonde & & 0.1 \\
\hline \multicolumn{5}{|c|}{ Chemical constituents } \\
\hline Alkalinity, as $\mathrm{CaCO}_{3}$ & $\mathrm{mg} / \mathrm{L}$ & & Titration & 1 \\
\hline Bromide, dissolved, as $\mathrm{Br}$ & $\mathrm{mg} / \mathrm{L}$ & & $\mathrm{IC}$ & 0.010 \\
\hline Calcium, dissolved, as $\mathrm{Ca}$ & $\mathrm{mg} / \mathrm{L}$ & & ICP & 0.022 \\
\hline Chloride, dissolved, as $\mathrm{Cl}$ & $\mathrm{mg} / \mathrm{L}$ & & $\mathrm{IC}$ & 0.06 \\
\hline Fluoride, dissolved, as F & $\mathrm{mg} / \mathrm{L}$ & & Ion-Selective Electrode & 0.04 \\
\hline Iron, dissolved, as $\mathrm{Fe}$ & $\mu \mathrm{g} / \mathrm{L}$ & & ICP & 4.0 \\
\hline Magnesium, dissolved, as $\mathrm{Mg}$ & $\mathrm{mg} / \mathrm{L}$ & & ICP & 0.011 \\
\hline Manganese, dissolved, as Mn & $\mu \mathrm{g} / \mathrm{L}$ & & ICP & 0.16 \\
\hline Potassium, dissolved, as $\mathrm{K}$ & $\mathrm{mg} / \mathrm{L}$ & & $\mathrm{ICP}$ & 0.03 \\
\hline Silica, dissolved, as $\mathrm{SiO}_{2}$ & $\mathrm{mg} / \mathrm{L}$ & & $\mathrm{ICP}$ & 0.018 \\
\hline Sodium, dissolved, as $\mathrm{Na}$ & $\mathrm{mg} / \mathrm{L}$ & & $\mathrm{ICP}$ & 0.06 \\
\hline Sulfate, dissolved, as $\mathrm{SO}_{4}$ & $\mathrm{mg} / \mathrm{L}$ & & IC & 0.09 \\
\hline $\begin{array}{l}\text { Solids, dissolved, sum of constituents } \\
\text { (SOC) }\end{array}$ & $\mathrm{mg} / \mathrm{L}$ & & Calculated & 1 \\
\hline $\begin{array}{l}\text { Solids, dissolved, residue on evaporation } \\
\text { (ROE) at } 180^{\circ} \mathrm{C}\end{array}$ & $\mathrm{mg} / \mathrm{L}$ & & Gravimetric & 20 \\
\hline Oxygen-18 $\left(\delta^{18} \mathrm{O}\right)$ & permil & & IRMS & NA \\
\hline Deuterium $\left(\delta^{2} \mathrm{H}\right)$ & permil & & IRMS & NA \\
\hline
\end{tabular}


0.91 to 1.0 , and the mean of the dissolved-solids concentration calculated by SOC was 97 percent of the ROE. Water with higher sulfate concentrations has been shown to yield an ROE value that exceeds the computed dissolved-solids value (Hem, 1989), which may explain some of the variability in the results.

Water samples were analyzed for major-ion concentrations and ROE at the USGS National Water Quality Laboratory (NWQL) in Lakewood, Colorado, using the analytical techniques described in Fishman and Friedman (1989). Stable isotope analyses were done at the USGS Stable Isotope Laboratory in Reston, Virginia, using analytical methods described in Révész and Coplen (2008). Discharge and water-quality data are stored in the publicly accessible USGS National Water Information System (NWIS) database and are available via the internet at http://waterdata.usgs.gov/ut/nwis/qw.

\section{Relation Between Specific Conductance and Dissolved-Solids Concentration}

Specific conductance was measured at all monitoring sites during sampling and continuously measured at selected locations; however, water samples were not analyzed for dissolved-solids concentration at every monitoring site. Specific conductance was used as a surrogate for determining the dissolved-solids concentration when water-quality samples were not collected. To assess potential differences in analysis methods, the relation between specific conductance and the dissolved-solids concentration was calculated with a linear least-squares regression equation separately for dissolvedsolids concentrations analyzed by ROE and SOC. Dissolvedsolids concentrations are also significantly different between low discharge tributaries and the main stem of the Colorado River. Therefore, separate linear least-squares regression equations were constructed for the main stem Colorado River and its tributaries for both ROE and SOC data (fig. $4 A$ ).

\begin{tabular}{lcccc}
\hline \multicolumn{1}{c}{$\begin{array}{c}\text { Total dissolved-solids } \\
\text { (TDS) data set }\end{array}$} & $\begin{array}{c}\text { Fig. 4 } \\
\text { plot }\end{array}$ & $\begin{array}{c}\text { Total dissolved- } \\
\text { solids method }\end{array}$ & $\begin{array}{c}\text { Regression } \\
\text { equation }\end{array}$ & $\mathbf{R}^{\mathbf{2}}$ \\
\hline Colorado River main stem & $\mathrm{A} / \mathrm{B} / \mathrm{C}$ & $\mathrm{SOC}$ & $0.608 \mathrm{x}+38.48$ & 0.81 \\
Tributaries to the Colorado River & $\mathrm{A}$ & $\mathrm{SOC}$ & $0.569 \mathrm{x}+59.27$ & 0.99 \\
Colorado River main stem & $\mathrm{A} / \mathrm{B} / \mathrm{C}$ & $\mathrm{ROE}$ & $0.545 \mathrm{x}+172.11$ & 0.55 \\
Tributaries to the Colorado River & $\mathrm{A}$ & $\mathrm{ROE}$ & $0.588 \mathrm{x}+72.67$ & 0.99 \\
Cisco, UT streamgage & $\mathrm{C}$ & $\mathrm{SOC}$ & $0.691 \mathrm{x}-63.23$ & 0.98 \\
Cisc0, UT streamgage & $\mathrm{C}$ & $\mathrm{ROE}$ & $0.718 \mathrm{x}-65.36$ & 0.96 \\
\hline
\end{tabular}

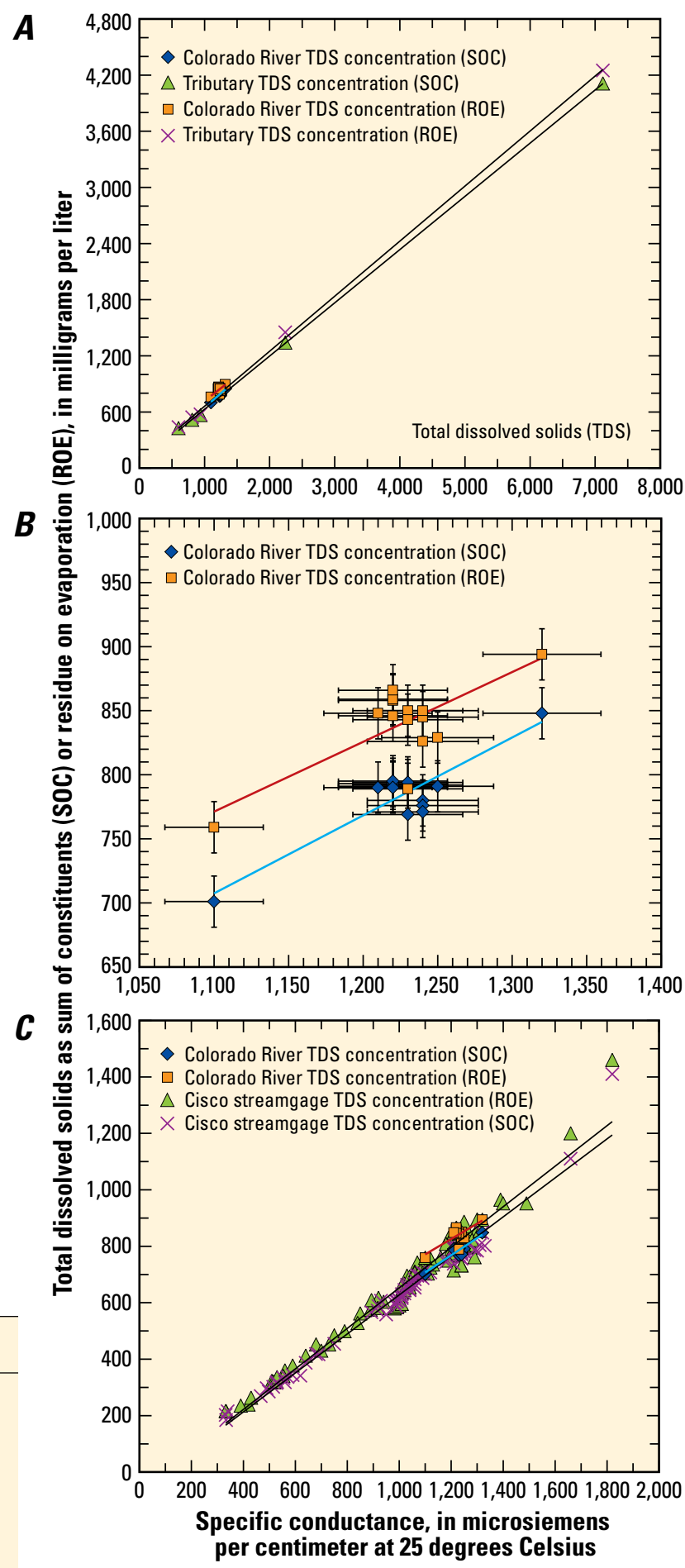

Figure 4. Specific conductance and total dissolved solids (TDS) least-squares relation developed from samples collected along the Colorado River between the Dolores River and Gypsum Canyon during four synoptic periods. $A$, Data from both Colorado River and tributary monitoring sites for dissolved-solids concentration; $B$, Data from Colorado River monitoring sites with error bars representing the accuracy in specific conductance from the calibration results and the accuracy in dissolved-solids concentration from the method reporting limit; and $C$, Data from the Colorado River monitoring sites plus historical specific-conductance and dissolved-solids concentration data collected at U.S. Geological Survey streamgaging station Colorado River near Cisco, Utah. 
The relation between dissolved-solids concentration determined by ROE and dissolved-solids concentration calculated by SOC versus specific conductance for the tributaries was similarly robust $\left(\mathrm{R}_{\mathrm{ROE}}^{2}=0.99, \mathrm{R}_{\mathrm{SOC}}^{2}=0.99\right)$. This indicates that dissolved-solids concentrations determined by ROE or SOC for the tributaries are consistent, and the dissolved-solid concentrations are well correlated with specific conductance. However, the correlation differed between dissolved-solids concentration by ROE and dissolved-solids concentration by SOC versus specific conductance for the main stem monitoring sites along the Colorado River $\left(\mathrm{R}^{2}{ }_{\mathrm{ROE}}=0.55, \mathrm{R}^{2}{ }_{\mathrm{SOC}}=\right.$ 0.81 ). The Pearson product-moment coefficient (correlation coefficient) between dissolved-solids concentrations by ROE and SOC for the Colorado River main stem was 0.87 , indicating a significant degree of linear dependence.

This difference in correlation between ROE and SOC for the main stem Colorado River monitoring sites was primarily due to the limited range in both specific conductance and dissolved-solids concentration (fig. $4 B$ ). To quantify the relation between specific conductance and dissolved-solids concentration in the Colorado River with higher accuracy, historical measurements at the USGS streamgage Colorado River near Cisco, UT (09180500) were incorporated for the period from 1999 through 2012. The large data set provided a much broader range of specific conductance and dissolved-solids concentration. The $\mathrm{R}^{2}$ for the dissolved-solids concentration using the larger representative Colorado River data set for SOC and ROE was 0.98 and 0.96 , respectively (fig. $4 C$ ).

\section{Dissolved-Solids Load}

Instantaneous discharge and dissolved-solids concentration at each monitoring site were used to estimate the continuous dissolved-solids load. Because the dissolved-solids concentrations were comparable between the analytical methods (ROE and SOC), results are presented using the SOC method. However, when the SOC method was not used for dissolvedsolids concentration, the ROE results were used. Instantaneous dissolved-solids loads were calculated as the product of the discharge and dissolved-solids concentration by

$$
W_{i}=Q_{i} * C_{i} * b
$$

where,

$i$ is the monitoring site,

$W$ is the total dissolved-solids load in tons per day,

$Q$ is the instantaneous discharge in $\mathrm{ft}^{3} / \mathrm{s}$,

$C$ is the dissolved-solids concentration in milligrams per liter, and

$b$ is $2.45 \times 10^{-3}$, a unit conversion factor.

\section{Dissolved-Solids Load Uncertainty}

Uncertainty in dissolved-solids load is estimated through multiplicative error propagation of the nonlinear loading calculation function. For the function $W(Q, C)$, the two variables are the river discharge $Q$ and the dissolved-solids concentration, $C$, and can be expanded as follows:

$$
\begin{aligned}
& f=f^{o}+\left(\frac{\delta f}{\delta Q}\right) Q+\left(\frac{\delta f}{\delta C}\right) C+2\left(\frac{\delta f}{\delta Q} \frac{\delta f}{\delta C}\right) Q C \\
& \sigma_{f}^{2}=\left(\frac{\delta f}{\delta Q}\right)^{2} \delta Q^{2}+\left(\frac{\delta f}{\delta C}\right)^{2} \delta C^{2}+2\left(\frac{\delta f}{\delta Q} \frac{\delta f}{\delta C}\right) \rho_{Q C}
\end{aligned}
$$

where,

$\rho \quad$ is the correlation coefficient between the arrays of $Q$ and $C$. When the function $f(A, B)=Q C$ is consistent with the loading calculation and

$$
\left(\frac{\delta f}{\delta Q}\right)=C,\left(\frac{\delta f}{\delta C}\right)=Q
$$

then the equation by Goodman (1960) is developed to calculate the exact variance. The Goodman (1960) equation can be stated as

$$
\begin{gathered}
\sigma_{f}^{2}=C^{2} \sigma_{Q}{ }^{2}+Q^{2} \sigma_{C}{ }^{2}+2 Q C \rho_{Q C}, \text { or } \\
\left(\frac{\sigma_{f}}{f}\right)^{2}=\left(\frac{\sigma_{Q}}{Q}\right)^{2}+\left(\frac{\sigma_{C}}{C}\right)^{2}+2\left(\frac{\sigma_{Q}}{Q}\right)\left(\frac{\sigma_{C}}{C}\right) \rho_{Q C}
\end{gathered}
$$

where,

$$
\begin{aligned}
& \sigma_{Q} \text { is the USGS qualitative evaluation rating of } \\
& \text { the discharge in cubic feet per second as a } \\
& \text { percentage. }
\end{aligned}
$$

As stated previously, the qualitative evaluation of discharge accuracy is further described elsewhere (Mueller and Wagner, 2009; Turnipseed and Sauer, 2010). The term $\sigma_{c}$ is the standard deviation of the concentration and is calculated as the standard deviation of all the dissolved-solids residuals about the estimated regression. Because $f$ is the dissolved-solids load, the total uncertainty in dissolved-solids loading is as follows:

$$
\sigma_{W}=\left[\sqrt{\left(\frac{\sigma_{Q}}{Q}\right)^{2}+\left(\frac{\sigma_{C}}{C}\right)^{2}+2\left(\frac{\sigma_{Q} \sigma_{C}}{Q C}\right) \rho_{Q C}}\right] Q C
$$

Dissolved-solids concentration was found to be negatively correlated to discharge with a correlation coefficient of -0.51 . It is necessary to include the correlation coefficient between the arrays of $Q$ and $C$ when calculating the variance. The uncertainty for each dissolved-solids load is shown in figure 5 . 


\section{Dissolved-Solids Load Spatial Comparison}

The dissolved-solids loads for each synoptic were examined as a function of downstream distance in the study reach to assess the effects of point sources and non-point sources on dissolved-solids loads in the Colorado River. Salt anticlines and salt domes along the study reach were hypothesized to be contributors to overall salt loading throughout this reach of the Colorado River (fig. 5).

Differences in dissolved-solids loads at monitoring sites on the main stem of the Colorado River between synoptics were minimal and typically within measurement uncertainty. During the first synoptic in September 2003, dissolved-solids loads at Colorado River monitoring sites above the confluence with the Green River did not increase above the measurement uncertainty. The Green River is a significant contributor of dissolved solids to the Colorado River, resulting in an increased load in the Colorado River below the confluence with the Green River (fig. 5). The Green River, at the time of the synoptic, contributed about 22 percent of the dissolved-solids load in the Colorado River downstream of the confluence.

During the second synoptic in early October 2010, variations in dissolved-solids loading between monitoring sites in the main stem of the Colorado River were negligible and were within measurement uncertainty. The monitoring site located on the main stem of the Colorado River below Salt Wash Rapids was sampled multiple times during the synoptic, and the calculated dissolved-solids loads at this location have the greatest differences. However, samples were collected over multiple days, and throughout this period the measured river discharge and specific conductance each varied by approximately 10 percent (fig. 5). Because the error bars do not overlap in this case, there is a true difference in dissolvedsolids loading. However, the higher dissolved-solids concentration associated with the sample collected on October 7 , 2010 , is not representative of the downstream concentration of dissolved solids along the reach because it was collected on a different day from the other samples when environmental conditions were different. These results indicate that Salt Wash could be a potential point source of dissolved solids; however, the magnitude of the contributed load is small and within the estimates of uncertainty. The results may also indicate non-steady state streamflow conditions rather than groundwater or surface water inputs. It is important to note that although the salt anticlines in the upper parts of the study reach including Fisher Valley, Cache Valley, Castle Valley, and Moab Valley (fig. 1) are potential dissolved-solids inputs, their dissolved-solids load contributions to the Colorado River were negligible at $9.98 \pm 9.26$ tons/d, or less than 1 percent of the average main stem load (7,077 \pm 444 tons/d). The tributaries of Onion Creek, Professor Creek, and Castle Creek showed increased specific-conductance values (up to six times greater than the Colorado River); however, the discharge in these tributaries is small, resulting in little impact to the Colorado River dissolved-solids load. The average tributary discharge was 0.03 percent of the Colorado River discharge, limiting the size of loads to the river. Salt Wash was the only tributary that may have contributed measurable dissolved-solids loads to the Colorado River.

The third synoptic was completed in late October 2010, and encompassed the entire study reach from the confluence of the Dolores River with the Colorado River to Gypsum Canyon. The results indicate substantial $(9,313 \pm 572$ tons/d) dissolvedsolids loading in the reach with a large contribution from the Green River. A slightly larger load than calculated in the first synoptic was determined for the Colorado River at Gooseneck monitoring site (382737109452101); however, the increase in load was within measurement uncertainty. The total dissolvedsolids load contributed from the Green River during this synoptic was approximately 23 percent of the loading at the downstream Colorado River at Gypsum Canyon monitoring site (375958110043601).

Results of the fourth synoptic completed in September 2011, are consistent with the previous three synoptics and indicate minimal dissolved-solids loading in the upper reach of the Colorado River. The dissolved-solids loads in the Colorado River near its confluence with Salt Wash indicate a 410 tons/d increase between monitoring sites above and below Salt Wash. The calculated total dissolved-solids load of Salt Wash was 4.9 tons/d, indicating the potential of additional groundwater discharge between the sites. However, the measurement uncertainty associated with the load at the site below Salt Wash Rapids was \pm 583 tons/d. Therefore, these results indicate that although Salt Wash contributed dissolved solids to the Colorado River, the load is negligible relative to the total dissolvedsolids load and uncertainty in the river.

Overall, the largest contributor of dissolved-solids load to the Colorado River is the Green River. The average dissolvedsolids load contribution of the Green River to the Colorado River determined from the first and third synoptics was 2,604 \pm 160 tons/d or approximately 22 percent of the dissolvedsolids load in the Colorado River downstream of its confluence with the Green River. The dissolved-solids load from all other measured tributaries was less than 0.33 percent of the load in the main stem of the Colorado River near Cisco, UT streamgage, at Lathrop Canyon, and above its confluence with Salt Wash, even though the specific conductance in the individual tributaries was as much as 16 times greater than the specific conductance in the Colorado River.

\section{Dissolved-Solids Load Comparison Between Synoptic Sampling Events}

Overall, the four synoptics showed minimal variability in dissolved-solids loading to the Colorado River between its confluence with the Dolores River and Gypsum Canyon (fig. 5). The upper part of the reach from the Colorado River near Cisco, UT streamgage to the Colorado River at J L Eddy was sampled in both early and late October 2010. The trends or increases in dissolved-solids loads with distance along the reach were similar between the second and third synoptics, although the average dissolved-solids load in the main stem 

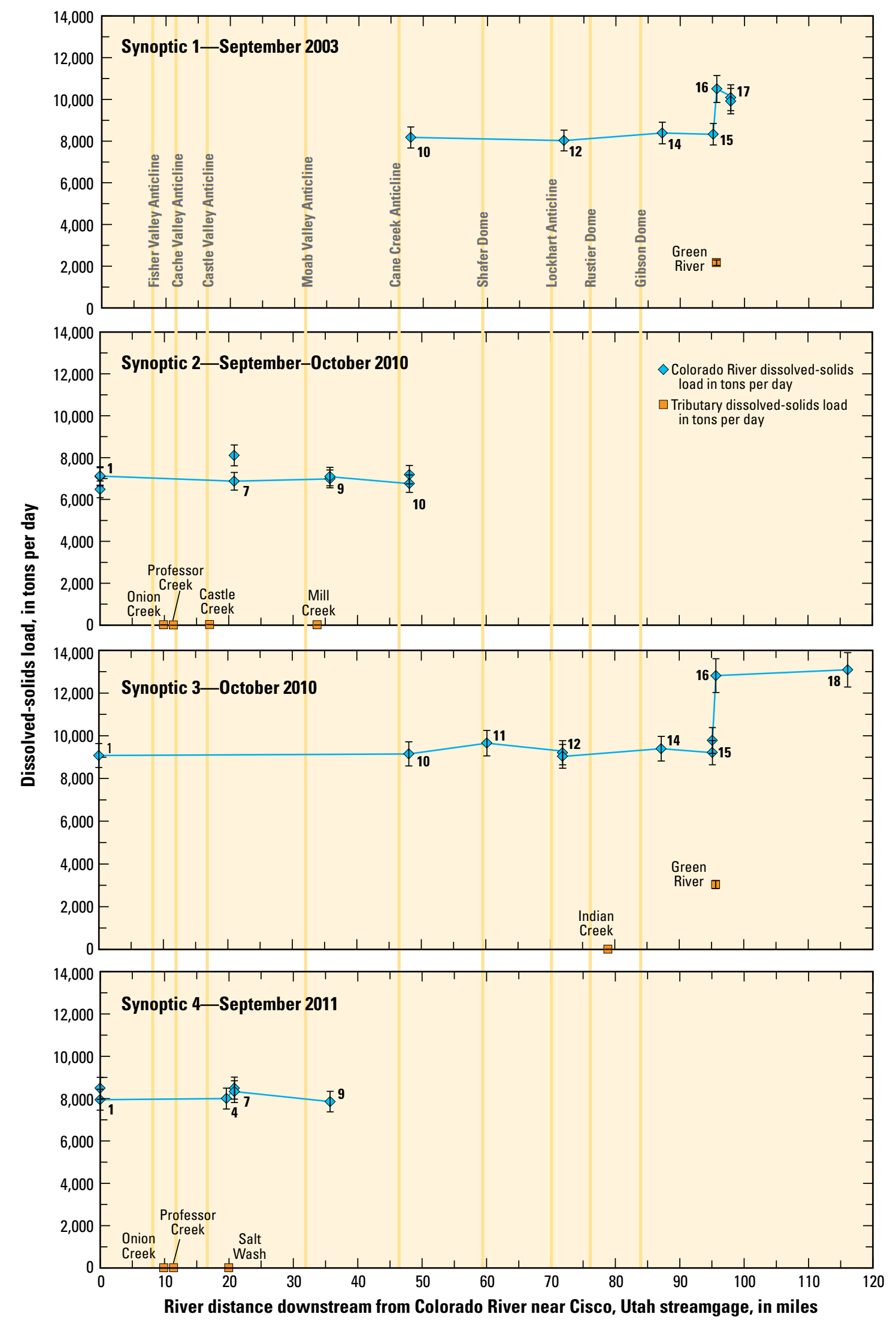

Figure 5. Dissolved-solids loading for each of the four synoptic sampling periods along the Colorado River between the Dolores River and Gypsum Canyon, southeastern Utah. 
Colorado River between each of the monitoring sites increased from 7,077 \pm 490 to $9,113 \pm 631$ tons/d, respectively, between the synoptics. A smaller subset of this upper reach from the Colorado River near Cisco, UT streamgage to the Colorado River at King's Bottom, was again analyzed in September 2011, and the average dissolved-solids load along the transect was $8,191 \pm 567$ tons/d. It would be expected that the loads were different between the synoptics as a function of temporally varying discharge. These results indicate that even during base-flow conditions, individual precipitation events, antecedent soil moisture conditions, and dissolved-solids storage reservoirs can substantially vary over time. The accumulation of dissolved solids between precipitation events can be stored throughout the terrestrial landscape and in depressions. As the length of time between events increases, the storage of dissolved solids would be expected to increase. To put the dissolved-solids load trends into perspective, a comparison of the load difference between the upstream reach (Colorado River near Cisco streamgage to J L Eddy) and the mid-reach (J L Eddy to the Green River) for each of the synoptics was done. The dissolved-solids load increased from the Colorado River near Cisco, UT streamgage to the J L Eddy monitoring site during the second synoptic ( $75 \pm 480$ tons/d) and the third synoptic ( $76 \pm 631$ tons/d). During the fourth synoptic, the Colorado River at King's Bottom site was monitored instead of the J L Eddy site. The difference between the two locations in the fourth synoptic was $-360 \pm 561$ tons/d, although the difference was $143 \pm 481$ tons/d in the second synoptic. With the exception of the load difference between the Colorado River near Cisco, UT streamgage and the Colorado River at King's Bottom during the fourth synoptic, the total dissolved-solids load in the upper reach increased with distance downstream. However, the increase and (or) decrease in dissolved-solids loads along the upper reach was well within measurement uncertainty. The difference in the dissolved-solids load between the J L Eddy site and the Colorado River above Green River confluence site increased as well, from $154 \pm$ 571 tons/d in the first synoptic to $342 \pm 649$ tons/d in the third synoptic. Although similar to the upper reach, the increase in dissolved-solids loads was well within the total measurement uncertainty.

The lower part of the Colorado River study reach was synoptically sampled in September 2003 and again in late October 2010. Similar to the upper part of the study reach, the variability in total dissolved-solids loading was consistent between synoptics and within measurement uncertainty. The only deviation from the statistically similar dissolved-solids load contributions was at monitoring sites on the Colorado River below the confluence with the Green River. The dissolvedsolids load contributed from the Green River was on average 28.5 percent of the load in the Colorado River above its confluence with the Green River. It is important to note that although the Green River dissolved-solids load ranged between 2,200 and 3,000 tons/d, the remainder of the tributaries to the Colorado River for the investigated reach averaged approximately 7.6 tons/d and ranged between 0.37 and 22.4 tons/d. Effectively, the Green River contributed approximately 25 percent of the total downstream dissolved-solids load to the Colorado River, while the remaining tributaries investigated during this study contributed less than 0.5 percent.

A potential concern of the Salinity Control Forum was whether the Intrepid Potash plant, located adjacent to the Colorado River (fig. 1), was a source of dissolved-solids loading to the Colorado River. Results from the first three synoptics in September 2003, mid-October 2010, and late October 2010, indicate that the Intrepid Potash plant had no discernible impact on Colorado River dissolved-solids loads and that any observed variability was within measurement uncertainty. There was evidence of increased dissolved-solids loading to the Colorado River downstream of the Intrepid Potash plant during the third synoptic; however, the increase was minimal and again, within the limits of uncertainty. Dissolved-solids loads in the reach of the Colorado River between its confluence with the Dolores River and the J L Eddy monitoring site indicated no significant salt inflow to the Colorado River for two of the four synoptics. Overall, the four synoptics completed in 2003, 2010, and 2011 between the Dolores River and Gypsum Canyon on the Colorado River during base-flow conditions, indicate that dissolved-solids loading does not increase in response to distributed or point sources associated with Paradox Formation salt domes, salt core anticlines, or any of the small tributaries.

\section{Chloride, Bromide, and Oxygen and Deuterium Isotope Concentrations}

Overall, the total dissolved-solids loads in the four synoptics indicate negligible dissolved-solids loading throughout the investigated reach of the Colorado River, with the exception of the Green River. An additional means to evaluate the spatial and temporal variability in salt loading was to examine variations in chloride and bromide concentrations and stable isotopes of oxygen $\left(\delta^{18} \mathrm{O}\right)$ and hydrogen (deuterium) $\left(\delta^{2} \mathrm{H}\right)$. Spatial and temporal trends in chloride, bromide, and oxygen and deuterium isotope concentrations were compared to estimate salt loading in the study reach.

\section{Chloride to Bromide Ratios}

Chloride and bromide are conservative constituents in the environment, and differences in the ratio of their concentrations can be used to indicate potential sources of groundwater discharge along a river reach (Whittemore, 1995; Davis and others, 1998). Chloride to bromide ratios exceeding 3,000:1 in water samples collected from shallow groundwater brine in Moab Valley were previously reported (U.S. Department of Energy, 2007), and ratios in samples collected from Paradox Valley groundwater brine were approximately 1,700:1 (Rosenbauer and others, 1992). Results indicate that the 
average chloride to bromide ratio in samples collected from the Colorado River study reach between the Dolores River and Gypsum Canyon was 1,494 (fig. 6).

The chloride concentrations in samples from monitoring sites in all four of the synoptics were relatively stable along the entire reach over time, with the exception of the September 2011 samples (fig. 6). Because adequate duplicate samples were not collected throughout this investigation, the analytical uncertainty for chloride and bromide concentrations was estimated by means of laboratory calculated QA/QC, as described in the Water Quality section of this report. The laboratory analytical error was used to define the analytical uncertainty. The analytical uncertainty was \pm 10 percent of the concentration value. Our observations indicate that although there are obvious deviations throughout the length of the study reach, the concentration values are within 10 percent. This estimate of error associated with chloride and bromide concentrations is considered conservative because it solely accounts for the analytical error and does not take into account in-situ and fieldbased measurement errors, which would increase the uncertainty. Because the September 2011 samples were collected under different flow and meteorological conditions than the early and late October 2010 samples, it would be expected that a deviation would result. Chloride concentrations for samples collected during the September 2011 synoptic sampling event were lower and did not change significantly downstream. The
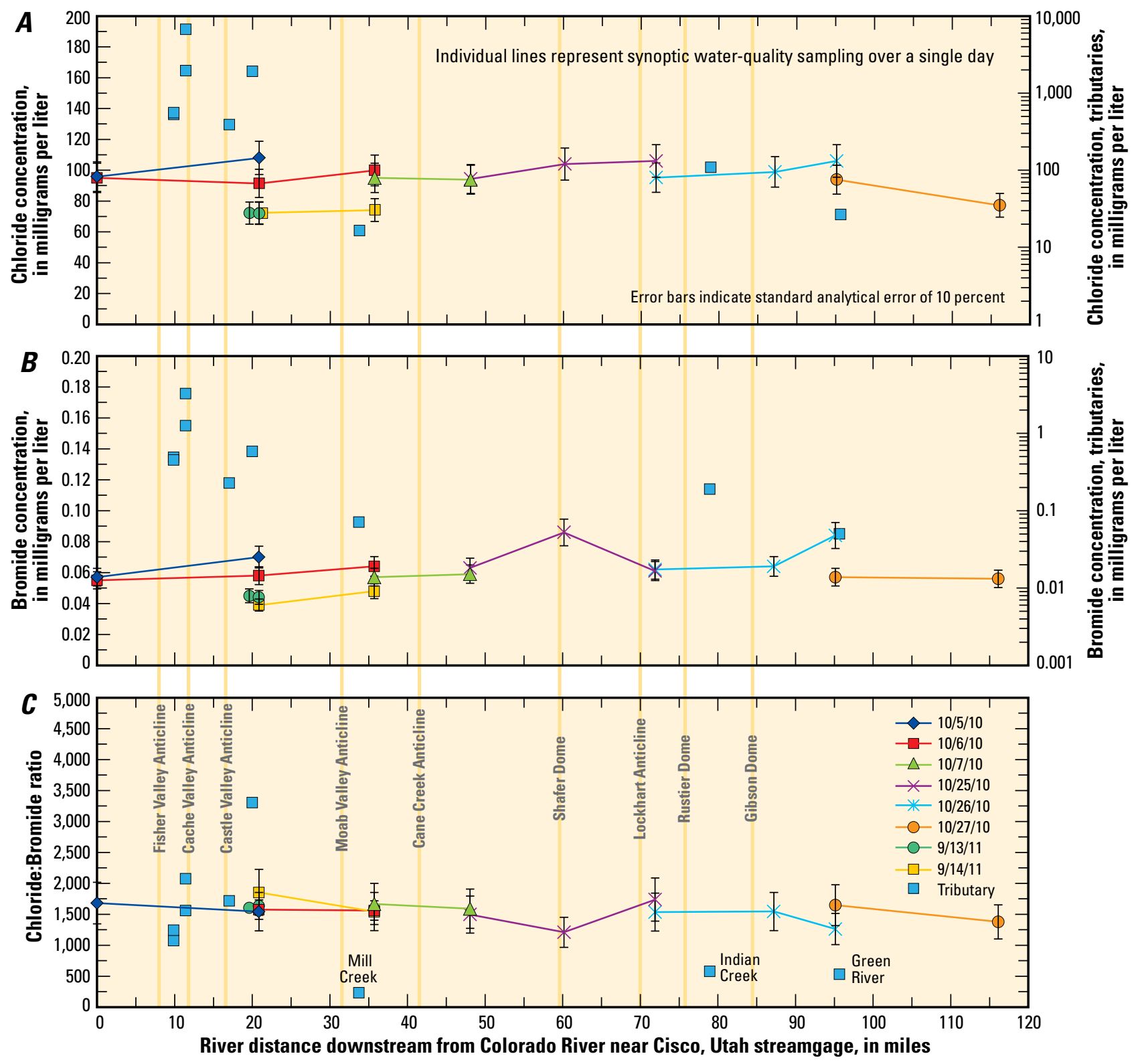

Figure 6. Chloride $A$, and bromide $B$, concentrations in the Colorado River and major tributaries during four synoptic sampling periods along the Colorado River between the Dolores River and Gypsum Canyon; and $C$, Chloride:bromide ratios for samples collected from the Colorado River and tributary monitoring sites. 
sample collected downstream of the confluence with the Green River showed a significant decrease in concentration. This is a result of the decreased chloride concentration in the Green River, which was approximately 30 percent of the average concentration in the Colorado River.

Bromide concentrations in samples from the four synoptics had similar patterns to chloride concentrations, with a few exceptions, including an increase at the Colorado River at Gooseneck site and no decreased concentrations below the Green River above Colorado River confluence site. Bromide concentrations in the study reach averaged $0.06 \mathrm{mg} / \mathrm{L}$. Again, the exception was the decreased concentration in the September 14, 2011 samples; however, the concentration trend was similar. There was a slight increase in bromide concentration in the sample collected from the Colorado River at Gooseneck site. This may be a result of the influence of potentially higher bromide concentrations due to the proximity of Shafer Dome (fig. 1). However, because the increase in concentration was not measured downstream, it is likely that the sample may be an outlier. Interestingly, samples collected from both the Colorado River above Green River confluence (site 381145109525201) and the Green River above Colorado River confluence (site 381116109540101), have slightly increased bromide concentrations, suggesting that local lithology is likely contributing to the increased bromide concentrations. This is further supported by the downstream bromide concentrations in samples from the Colorado River at Gypsum Canyon monitoring site (site 375958110043601 ), which are similar to the upstream bromide concentrations.

The chloride and bromide concentrations in tributary samples are mostly orders of magnitude greater than the concentrations in the Colorado River; however, the tributary loads as described previously, are very small relative to loads in the Colorado River. Therefore, changes in chloride and bromide concentrations in the Colorado River from the tributary loads were not discernible. Samples collected from the Green River (site 381116109540101), Mill Creek (site 383427109341501), and to a lesser extent Indian Creek (site 381741109465901), have lower concentrations of chloride and bromide than the Colorado River main stem or other sampled tributaries. Tributaries in the upper part of the reach near Castle Valley have much higher chloride and bromide concentrations while downstream tributaries have about two orders of magnitude lower chloride and bromide concentrations. The relative incision of the individual streams into the underlying strata has the potential to increase salt dissolution and instream chloride and bromide concentrations. It is possible that the underlying evaporites associated with the Paradox Formation are closer to the land surface in the northern reaches and influence tributary water quality in these areas. However, the precise identification of sources contributing to the salinity of tributary inflows was outside the scope of this investigation.

By examining the chloride to bromide ratios at each of the monitoring sites in the Colorado River study area, the influences of different lithologies and hydrologic contributions can be identified and investigated. Similar to the trends observed in chloride and bromide concentrations in the study reach, there is no significant difference in chloride to bromide ratios from samples collected at main stem sites on the Colorado River, with the exception of the Green River. Overall, the chloride and bromide concentrations at monitoring sites throughout the study reach complement the dissolved-solids loads at these sites, where there is not a discernible difference in chloride and bromide loads along the Colorado River main stem.

\section{Oxygen and Deuterium Isotopes}

Oxygen $\left(\delta^{18} \mathrm{O}\right)$ and deuterium $\left(\delta^{2} \mathrm{H}\right)$ stable isotopes can be used to identify possible sources of groundwater and salinity. Groundwater discharge contributions to the Colorado River from the Paradox Basin evaporites should be isotopically enriched with heavier isotope concentrations relative to the Colorado River. In figure 7, the $\delta^{18} \mathrm{O}$ and $\delta^{2} \mathrm{H}$ isotopic signatures plot near the global meteoric water line (GMWL) for samples collected at all the monitoring sites. The GMWL was determined by using the empirical equation developed by Craig (1961), where $\delta^{2} \mathrm{H}=8.13 * \delta^{18} \mathrm{O}+10.8$.

There was considerable variability in isotope concentrations in samples from individual monitoring sites, particularly the tributary monitoring sites (fig. 7). The sample from Indian Creek was substantially heavier isotopically than any of the other samples, and the Green River, Onion Creek (site 384357109212001), and Professor Creek (site 384248109222101) samples were each heavier than the Colorado River samples. The Castle Creek near Moab, UT streamgaging site (station 09182500) sample was isotopically similar to the samples collected from the Colorado River. The isotopic signature of the Green River sample plots below the GMWL, indicating increased evaporative fractionation. Isotopic values from all Colorado River samples plot on a trendline with a similar slope as the GMWL (fig. 7, inset); however, the samples appear to be on average 1.10 permil lighter in $\delta^{2} \mathrm{H}$. The trendline of the Colorado River samples, referred to as the local meteoric water line, was defined by the equation $\delta^{2} \mathrm{H}=$ $7.77 * \delta^{18} \mathrm{O}+4.03$. Although it is difficult to elucidate a spatial pattern in the Colorado River isotopic analysis, the inset in figure 7 shows a possible trend of isotopically lighter samples in the upper part of the reach and isotopically heavier samples in the lower part of the reach. 


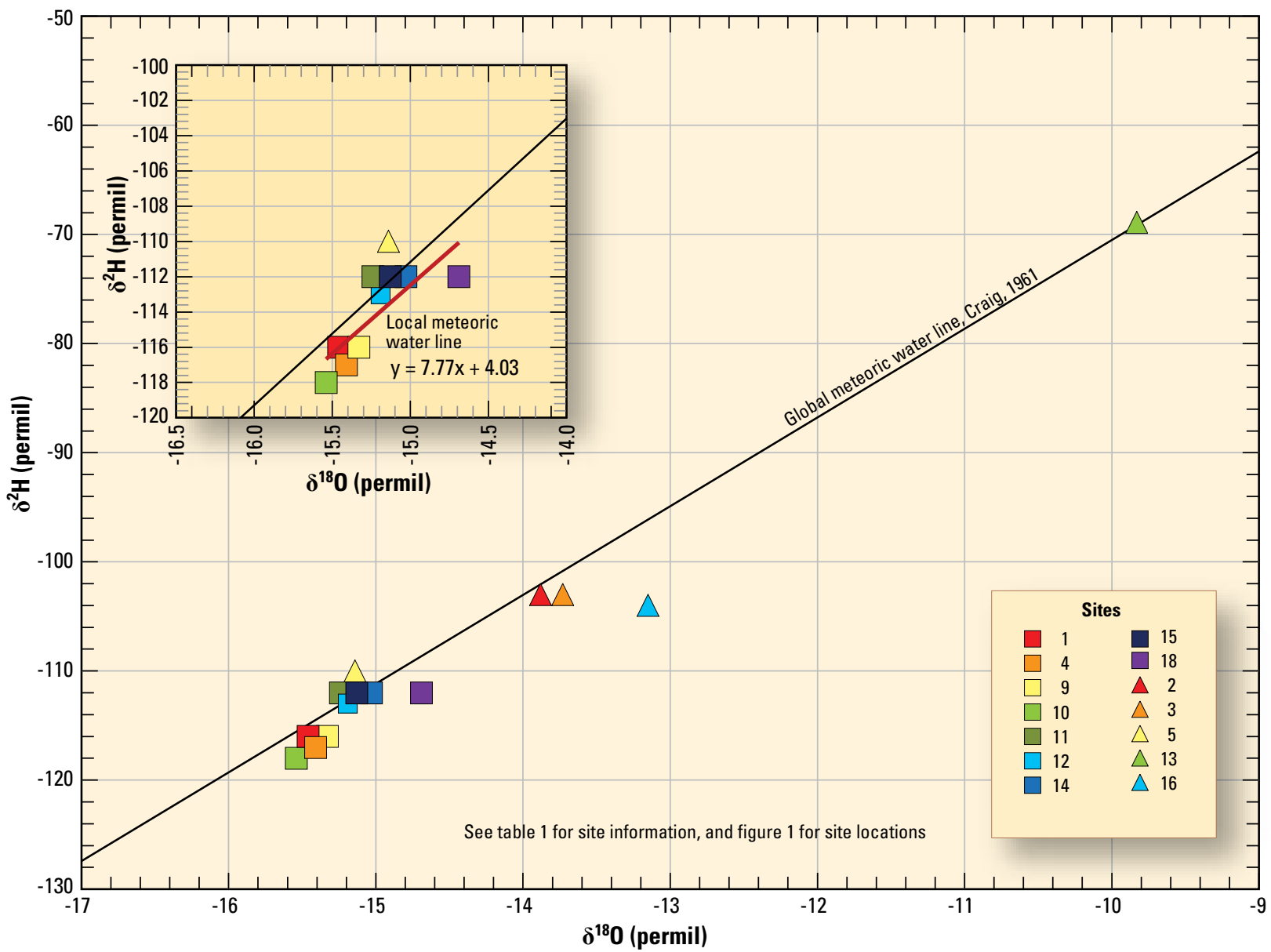

Figure 7. Oxygen $\left(\delta^{18} 0\right)$ and deuterium $\left(\delta^{2} \mathrm{H}\right)$ concentrations in samples collected from the Colorado River and tributary monitoring sites between the Dolores River and Gypsum Canyon, southeastern Utah.

\section{Summary and Conclusions}

Because of the 1974 passage of the Colorado River Basin Salinity Control Act, the Colorado River Basin Salinity Control Program was developed and tasked to improve Colorado River water quality above Imperial Dam. Since the program implementation, control measures have been instituted, reducing the salinity of the Colorado River. However, damages to United States stakeholders are projected to continue to increase without further reduction measures. The Colorado River between its confluence with the Dolores River and Lake Powell, traverses a physiographic area where saline sedimentary formations and evaporite deposits are prevalent. The purpose of this study was to calculate dissolved-solids loads in this reach of the Colorado River, assess if there is significant salinity loading and if so, determine the sources of the loads. This report presents the results of four synoptic events where discharge was measured and water-quality samples were collected from the Colorado River and its tributaries between the Dolores River and Gypsum Canyon above Lake Powell. Estimates of total dissolved-solids loading and the associated uncertainty are quantified and compared with chloride and bromide concentrations, and the stable isotopes of oxygen and deuterium.
Results of the four synoptics indicate negligible dissolvedsolids loading to the Colorado River throughout the study reach, with the exception of the Green River. There was no significant increase in Colorado River dissolved-solids loads in the reach that bracketed the Intrepid Potash plant. The average dissolved-solids load contribution from the Green River to the Colorado River was about 22 percent, while the dissolvedsolids loads from the remaining tributaries were less than 0.33 percent. Salt anticlines in the upper reach of the Colorado River study area are traversed by several tributaries including Onion Creek, Professor Creek, and Castle Creek, which had specific-conductance values as much as 16 times greater than the Colorado River. The discharge from each of the tributaries was small, resulting in negligible dissolved-solids loading to the Colorado River. The average tributary discharge was 0.03 percent of the Colorado River discharge.

Chloride and bromide concentration trends are consistent with dissolved-solids loading trends along the investigated reach. Results indicate a relatively consistent trend in concentrations, with the exception of the influence of the Green River. These results are further supported by the stable isotope 
analyses. Overall, the four synoptics completed between 2003 and 2011 along the reach of the Colorado River from its confluence with the Dolores River to Gypsum Canyon during base-flow conditions, indicate that dissolved-solids loads do not increase. During the synoptic studies, the Paradox Formation, local salt anticlines, the Intrepid Potash evaporation ponds, and perennial tributaries did not appear to be significant sources of salinity to the Colorado River during base-flow conditions. However, significant changes to the hydrologic system in the future due to anthropogenic activities or perhaps climate change may alter groundwater flow paths and total dissolved-solids loading to the Colorado River.

\section{References Cited}

Barnett, J., 2008, Limiting salt loading to the Colorado River: Southwest Hydrology, v. 7, no. 2, p. 22-23.

Buchanan, T.J., and Somers, W.P., 1969, Discharge measurements at gaging stations: U.S. Geological Survey Techniques of Water-Resources Investigations, book 3, chap. A8, 65 p., also available at http://pubs.usgs.gov/twri/twri3a8/.

Cater, F.W., 1970, Geology of the salt anticline region in southwestern Colorado: U.S. Geological Survey Professional Paper 637, 80 p., also available at http://pubs.usgs.gov/pp/0637/report.pdf.

Chafin, D.T., 2003, Effect of the Paradox Valley Unit on the dissolved-solids load of the Dolores River near Bedrock, Colorado, 1988-2001: U.S. Geological Survey Water-Resources Investigations Report 02-4275, 6 p., also available at http://pubs.usgs.gov/wri/wri02-4275/pdf/wrir02-4275.pdf.

Clow, D.W., Mast, M.A., and Campbell, D.H., 1996, Controls on surface water chemistry in the Upper Merced River Basin, Yosemite National Park, California: Hydrological Processes, v. 10, p. 727-746.

Craig, H., 1961, Isotopic variations in meteoric waters: Science, v. 133, p. 1702-1703.

Davis, S.N., Whittemore, D.O., and Fabryka-Martin, J., 1998, Uses of chloride/bromide ratios in studies of potable water: Ground Water, v. 36, p. 338-350, doi: 10.1111/j.17456584.1998.tb01099.x.

Edward, T.K., and Glysson, G.D., 1999, Field methods for measurement of fluvial sediment: U.S. Geological Survey Techniques of Water-Resources Investigations, book 3, chap. C2, 89 p.

Eyre, B.D., and Pepperell, P., 1999, A spatially intensive approach to water quality monitoring in the Rous River catchment, NSW Australia: Journal of Environmental Management, v. 56, p. 97-118.
Fetter, C.W., 1994, Applied hydrogeology: Prentice Hall, Englewood Cliffs, New Jersey, 598 p.

Fishman, M.J., and L.C. Friedman, eds., 1989, Methods for the determination of inorganic substances in water and fluvial sediments: U.S. Geological Survey Techniques of Water-Resources Investigations, book 5, chap. A1, 545 p., also available at http://pubs.usgs.gov/twri/twri5-al/.

Gardner, R.L., and Young, R.A., 1985, An economic evaluation of the Colorado River Basin salinity control program: Western Journal of Agricultural Economics, v. 10, no. 1, p. 1-12.

Goodman, L., 1960, On the exact variance of products: Journal of the American Statistical Association, v. 55, no. 292, p. 708-713, doi:10.2307/2281592. JSTOR 2281592.

Grayson, R.B., Gippel, C.J., Finlayson, B.L., and Hart, B.T., 1997, Catchment-wide impacts on water quality: The use of "snapshot" sampling during stable flow: Journal of Hydrology, v. 199, p. 121-134.

Gutierrez, F., 2004, Origin of the salt valleys in the Canyonlands section of the Colorado Plateau-Evaporite-dissolution collapse versus tectonic subsidence: Geomorphology, v. 57, p. 423-435, doi:10.1016/S0169-555X(03)00186-7.

Hanshaw, B.B., and Hill, G.A., 1969, Geochemistry and hydrodynamics of the Paradox Basin region, Utah, Colorado and New Mexico: Chemical Geology, v. 4, p. 263-294.

Hem, J.D., 1989, Study and interpretation of the chemical characteristics of natural water: U.S. Geological Survey Water-Supply Paper 2254, 263 p., also available at http://pubs.usgs.gov/wsp/wsp2254/html/pdf.html.

Hite, R.J., 1961, Potash-bearing evaporite cycles in the salt anticlines of the Paradox Basin, Colorado and Utah: U.S. Geological Survey Professional Paper 424D, p. D136D138.

Hite, R.J., and Lohman, S.W., 1973, Geologic appraisal of Paradox Basin salt deposits for waste emplacement: U.S. Geological Survey Open-File Report 73-114, 75 p., also available at http://pubs.usgs.gov/of/1973/0114/report.pdf.

Hood, J.W., and Danielson, T.W., 1979, Bedrock aquifers in the lower Dirty Devil River basin area, Utah, with special emphasis on the Navajo Sandstone: U.S. Geological Survey Open-File Report 79-1163, 85 p. (superseded by Utah Department of Natural Resources Technical Publication 68).

Huntoon, P.W., 1977, The hydrogeologic feasibility of developing ground-water supplies in the northern part of Canyonlands National Park and Natural Bridges National Monument, Utah: Wyoming Water Resources Research Institute, Laramie, Wyoming, 24 p. 
Iorns, W.V., Hembree, C.H., and Oakland, G.L., 1965, Water resources of the Upper Colorado River Basin-Technical Report: U.S. Geological Survey Professional Paper 441, 370 p., also available at http://pubs.usgs.gov/pp/0441/report.pdf.

Kenney, T.A., Gerner, S.J., Buto, S.G., and Spangler, L.E., 2009 , Spatially referenced statistical assessment of dissolved-solids load sources and transport in streams of the Upper Colorado River Basin: U.S. Geological Survey Scientific Investigations Report 2009-5007, 50 p., also available at http://pubs.usgs.gov/sir/2009/5007/.

Mueller, D.S., and Wagner, C.R., 2009, Measuring discharge with acoustic Doppler current profilers from a moving boat: U.S. Geological Survey Techniques and Methods 3A-22, 72 p., also available at http://pubs.water.usgs.gov/tm3a22.

Rantz, S.E., and others, 1982a, Measurement and computation of streamflow: Volume 1. Measurement of stage and discharge: U.S. Geological Survey Water-Supply Paper 2175, v. 1, 284 p., also available at http://pubs.usgs.gov/ wsp/wsp2175/html/WSP2175_vol1_pdf.html.

Rantz, S.E., and others, 1982b, Measurement and computation of streamflow: Volume 2. Computation of discharge: U.S. Geological Survey Water-Supply Paper 2175, v. 2, 316 p., also available at http://pubs.usgs.gov/wsp/wsp2175/html/ wsp2175_vol2.html.

Révész, K., and Coplen, T.B., 2008, Determination of the $\delta\left({ }^{18} 0 /{ }^{16} 0\right)$ of water: RSIL lab code 489 , chap. C2, in Révész, Kinga, and Coplen, Tyler B., eds., Methods of the Reston Stable Isotope Laboratory: U.S. Geological Survey Techniques and Methods, book 10, chap. C2, 28 p., also available at http://pubs.usgs.gov/tm/2007/tm10c2/.

Rosenbauer, R.J., Bischoff, J.L., and Kharaka, Y.K., 1992, Geochemical effects of deep-well injection of the Paradox Valley brine into Paleozoic carbonate rocks, Colorado, U.S.A.: Applied Geochemistry, v. 7, no. 3, p. 273-286.

Rush, F.E., Hart, I.M., Whitfield, M.S., Giles, T.F., and D' Epagnier, T.E., 1980, Results of hydraulic tests in wells DOE-1, 2, 3, Salt Valley, Grand County, Utah: U.S. Geological Survey Open-File Report 80-205, 38 p., also available at http://pubs.usgs.gov/of/1980/0205/report.pdf.

Rush, F.E., Whitfield, M.S., and Hart, I.M., 1982, Regional hydrology of the Green River-Moab area, northwestern Paradox Basin, Utah: U.S. Geological Survey Open-File Report 82-107, 92 p., also available at http://pubs.usgs.gov/of/1982/0107/report.pdf.

Trudgill, B.D., 2011, Evolution of salt structures in the northern Paradox Basin: Controls on evaporite deposition, salt wall growth and supra-salt stratigraphic architecture: Basin Research, v. 23, p. 208-238, doi: 10.1111/j.13652117.2010.00478.x.
Turnipseed, D.P., and Sauer, V.B., 2010, Discharge measurements at gaging stations: U.S. Geological Survey Techniques and Methods, book 3, chap. A8, 87 p., also available at http://pubs.usgs.gov/tm/ tm3-a8/.

U.S. Bureau of Reclamation, Upper Colorado Region, 2005, Quality of water, Colorado River Basin, Progress Report No. 22, 69 p., also available at http://www.usbr.gov/uc/progact/salinity/pdfs/PR22.pdf.

U.S. Bureau of Reclamation, Upper Colorado Region, 2011, Quality of water, Colorado River Basin, Progress Report No. 23, 76 p., also available at http://www.usbr.gov/uc/progact/salinity/pdfs/PR23final.pdf.

U.S. Department of Energy, 2007, Fall 2006 assessment of Matheson wetlands hydrogeology and ground water chemistry: Doc. No. X0200300, 62 p. plus appendices, also available at http://www.gjem. energy.gov/moab/documents/gs_water/remedial_actions/fall2006_ assmt.pdf.

U.S. Environmental Protection Agency, Regions 8 and 9, 1971, The mineral quality problem in the Colorado River Basin, v. 1-5, 65 p.

U.S. Geological Survey, variously dated, National field manual for the collection of water-quality data: U.S. Geological Survey Techniques of Water-Resources Investigations, book 9, chap. A1-A9, also available at http://pubs.water.usgs.gov/twri9A.

Whittemore, D.O., 1995, Geochemical differentiation of oil and gas brine from other saltwater sources contaminating water resources: Case studies from Kansas and Oklahoma: Environmental Geosciences, v. 2, p. 15-31.

Wollitz, L.E., Thordarson, W., Whitfield, M.S., and Weir, J.E., 1982, Results of hydraulic tests in U.S. Department of Energy's wells DOE-4, 5, 6, 7, 8, and 9, Salt Valley, Grand County, Utah: U.S. Geological Survey Open-File Report 82-346, 78 p., also available at http://pubs.usgs.gov/of/1982/0346/report.pdf. 

